\title{
Inequality and Its Discontents
}

\section{Brian Nolanª, Luis Valenzuelaa}

a Institute for New Economic Thinking and Department of Social Policy and Intervention, University of Oxford

\begin{abstract}
Inequality in the distribution of income and wealth has come to the fore as a core concern across the industrialised world. Here we examine what has happened to income inequality across the rich countries in recent decades. We discuss the range of factors that appear to be driving inequality upwards, notably the role of technological change, globalisation, and national institutions and policies. We look at how rising inequality might undermine economic growth and squeeze the middle, and assess the extent to which it has actually done so. We assess whether rising inequality is associated with worsening outcomes and inequalities across various social domains. Finally, we review emerging evidence on the role that rising inequality may be playing in the 'revolt of the angry' and rise of populism.
\end{abstract}




\section{Inequality and Its Discontents}

\section{INTRODUCTION}

Inequality in the distribution of income and wealth has now come to the fore as a core concern across the industrialised world. In 2013 then President of the United States Barack Obama identified rising income inequality as "the defining challenge of our times". The Managing Director of the International Monetary Fund Christine Lagarde has stated that "reducing excessive inequality is not just morally and politically correct, but it is good economics." Secretary-General of the OECD Angel Gurría has emphasized that "Inequality can no longer be treated as an afterthought. We need to focus the debate on how the benefits of growth are distributed". This reflects the fact that inequality has been rising in many rich countries, and that this is seen as undermining economic growth, 'squeezing' middle and lower income households, exacerbating social 'bads' such as health inequalities, and undermining social solidarity and trust. Most recently, in light of political developments, it has also been held responsible for fuelling the rise of populism.

To explore this 'grand narrative', we first examine what has happened to income inequality across the rich countries in recent decades, also summarising what is known about trends in the distribution of wealth. We discuss the range of factors that appear to be driving inequality upwards, notably the role of technological change, globalisation, and national institutions and policies. We look at how rising inequality might undermine economic growth and squeeze the middle, and assess the extent to which it has actually done so. We discuss how rising inequality may be associated with worsening outcomes and inequalities across various social domains. Finally, we look at the robustness of the claim that rising inequality has driven the 'revolt of the angry' and rise of populism.

\section{INCOME INEQUALITIES IN OECD COUNTRIES: PATTERNS AND TRENDS}

Comparative data on income inequality in rich countries is usually taken from databases such as the Luxembourg Income Study (LIS) or the OECD Income Distribution database (OECD IDD), or, when developing countries are also being included, from sources such as the World Bank's Povcalnet database, UN-WIDER's World Income Inequality Database, or the Standardized World Income Inequality 
Database compiled by Solt (2016). These often cover different periods and the picture seen over recent years for a given country may well differ across these sources, for that and other reasons (as brought out in Nolan, 2018a, Chapter 3).

To get a more consistent picture, here we draw first on data from a variety of sources - the LIS, OECD, the Growing Inequalities' Impacts (GINI) comparative project and the Chartbook of Economic Inequality (Atkinson et al, 2017), making a judgement about the most suitable source for current purposes for each country. This allows us to capture patterns and trends in income inequality going back close to 1980, to see the longer-run trends up to the onset of the financial and economic crisis in 2007-08. We then focus on what happened to inequality during and after the Great Recession, relying for that on the OECD database which includes annual data over those years for most of the countries we wish to cover.

Income inequality is captured first by the most commonly-used summary measure, the Gini coefficient, which reflects income differences across the distribution and ranges from 0 , indicating no inequality, up to 1 which indicates maximum inequality. The income concept employed, as is usual, is equivalised disposable income - in other words, income from the market plus cash transfers minus direct taxes (including employee social insurance contributions), adjusted for differences in household size to take the greater needs of larger households into account.

Table 1 shows the direction and extent of movement in the Gini coefficient inequality measure from around 1980 (or as close as possible) to about 2007 for OECD countries. The most common pattern is rising inequality. However, there are countries where inequality was stable (such as France and Ireland) and ones where it declined (such as Greece and Portugal). Furthermore, among those where inequality rose, the scale of that increase varied widely: for some it was relatively modest, whereas for others the Gini coefficient rose markedly. The most substantial increases were for Finland, Sweden and the UK; the USA was in the group with the next-highest rise, and this was from a particularly high initial level. As pointed out in Förster and Tóth (2015), there was some tendency for inequality to fall or remain stable where it was initially relatively high, while some of the larger increases were in countries which has relatively low levels at the outset of the period such as some of the Nordic and Baltic countries. This meant that some degree of convergence in inequality levels was observed. 
Table 1: Income Inequality from About 1980 to Before the Crisis: Change in Gini Coefficient

\begin{tabular}{lc}
\hline & Change in Gini from Around 1980 to 2007 \\
\hline Australia & +0.06 \\
Austria & +0.02 \\
Belgium & +0.03 \\
Bulgaria & +0.11 \\
Canada & +0.03 \\
Czech Republic & +0.02 \\
Denmark & +0.02 \\
Estonia & +0.08 \\
Finland & +0.06 \\
France & -0.04 \\
Germany & +0.05 \\
Greece & -0.02 \\
Hungary & +0.07 \\
Ireland & 0 \\
Italy & -0.01 \\
Japan & +0.02 \\
Latvia & +0.12 \\
Lithuania & +0.13 \\
Luxembourg & +0.04 \\
Netherlands & +0.03 \\
New Zealand & +0.06 \\
Norway & +0.02 \\
Poland & +0.07 \\
Portugal & -0.03 \\
Romania & +0.12 \\
Slovak Republic & +0.03 \\
Slovenia & -0.01 \\
Spain & -0.01 \\
Sweden & +0.09 \\
Switzerland & -0.01 \\
United Kingdom & +0.10 \\
United States & +0.07 \\
Average & +0.04 \\
\hline \multicolumn{1}{|c|}{ Source: } & \\
\hline
\end{tabular}

Source: LIS, OECD IDD, Chartbook of Economic Inequality, GINI Project Database

An overarching conclusion from these figures is that a simple summary along the lines of "Income inequality has increased in most rich countries in the decades up to the Crisis" is valid as far as it goes, but risks obscuring major, consequential differences in country experiences. An increase of 1 or 2 Gini points represents a very different reality to an increase of 6 or 8. (Leaving aside questions of accuracy of measurement and purely statistical significance, Atkinson, 2015, for example argues 
that a change of 3 points in the Gini is certainly substantively 'salient'.) Furthermore, an increase even of the scale of 6-8 points in the Gini from a very low initial base level, as in the Czech Republic or Sweden, represents a very different reality to a similar increase from an already high level, as in the case of the UK or more especially the USA.

It is also very important to note that inequality most often did not rise in a smooth or consistent fashion over time: instead, in many countries much of the increase in inequality was concentrated in discrete sub-periods or 'episodes', as highlighted by Tóth (2014) and Atkinson (2015). This is most dramatically the case of the countries experiencing transition from state socialism in the 1990s, but there are many other examples. In the UK, for example, overall inequality grew rapidly in the 1980s, in the Thatcher era, but was rather stable from about 1995. Sweden saw some periods when inequality rose very rapidly, notably in economic crisis it experienced in the 1990s, and others where it fell. Even for the US, often seen as the exemplar of continuously increasing inequality over decades, that increase was rather more rapid before about 1995 than after it.

Turning to what happened to income inequality from the onset of the Crisis, Table 2 brings out that income inequality then went down or was stable as often as it increased. Even among the countries worst hit by the crisis in terms of GDP per head and average household income, some saw inequality rise markedly but others (for example Ireland and Portugal) did not. In-depth studies of the impact of recession on income inequality (for example Jenkins et al, 2013) highlight the complex channels through which incomes from different sources (notably earnings, self-employment income and social protection transfers) are affected. This brings out that the impact on overall inequality depends on how profits are affected, on how much unemployment rises and how that affects households across the income distribution, and on the response of the tax and transfer system, both in terms of automatic 'stabilisers' and discretionary policy choices in response to increasing demands on the system and fiscal deficits. The effects of the Great Recession on absolute income levels, deprivation, poverty and social exclusion can be captured by a variety of other indicators: focusing purely on the distribution rather than the level of incomes, though, the recession has had varying effects rather than simply or consistently reinforced previous trends towards increasing inequality. 
Table 2: Income Inequality Through the Crisis: Change in Gini Coefficient

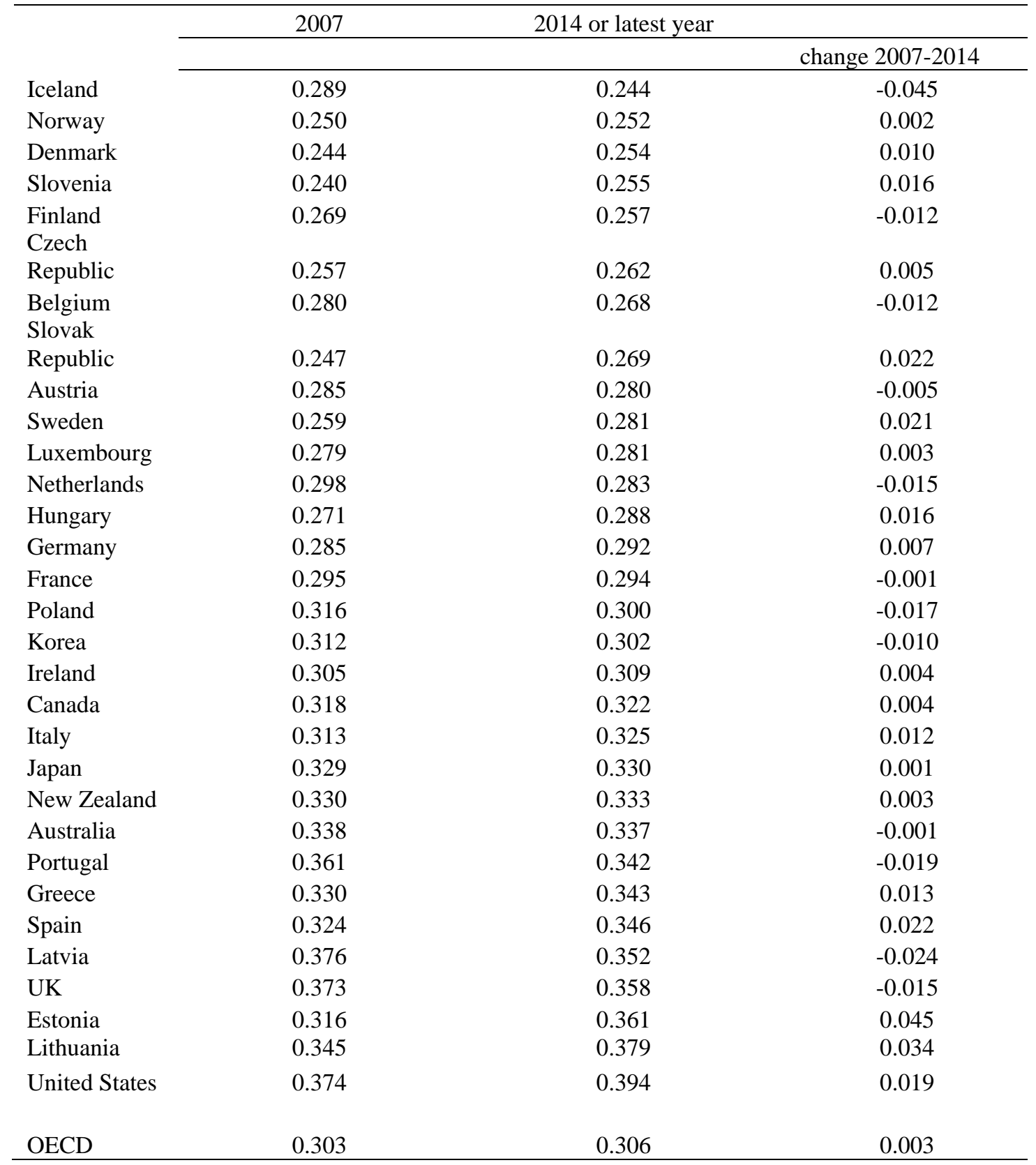

Source: OECD Income Distribution Database

To capture and convey what has been happening at different points across the distribution, it is helpful to complement the Gini summary measure by also looking at, for example, measures based on percentile ratios. The ratio of the $90^{\text {th }}$. to the $10^{\text {th }}$. percentile will by construction not be affected by what is happening to income shares at the very top or bottom, unlike the Gini coefficient, while capturing what is happening across the broad mass of the income distribution. This indicator of inequality also rose from the early-mid-1980s in most of the countries covered, the 
exceptions being Austria, Iceland, Ireland, and Portugal where it fell, and Denmark, France and Switzerland where it was little changed. Countries where the Gini rose markedly generally also saw P90/P10 rise substantially, though there is by no means a perfect alignment between the two measures - for example, Japan saw a sharp rise in $\mathrm{P}_{90} / \mathrm{P}_{10}$ but only a quite limited increase in the Gini.

So far we have been concerned with inequality across the entire distribution. However, in the debate about rising inequality a great deal of attention has focused on what has been happening at the very top of the distribution, in terms of the share of income going to the top $1 \%$ or even the top $0.1 \%$. This has only been possible because of the collaborative research effort driven by Tony Atkinson and Thomas Piketty (see for example Atkinson and Piketty, 2007, 2010, Atkinson, Piketty and Saez, 2011, Alvaredo et al, 2012) to produce estimates of these shares for many countries, which has transformed research and debate about inequality trends. These estimates follow a common approach and are based on information collected for income tax purposes together with the national accounts, rather than from surveys that, for a variety of reasons, find it difficult to capture that part of the distribution well. The World Inequality Database (formerly the World Income and Wealth Database) brings together these estimates (see http://wid.world). They are only available for some OECD countries, and refer to the share of the top in gross (before income tax and social insurance contributions) rather than disposable income, and to the tax unit rather than the household. ${ }^{1}$ This makes it difficult to align them with survey-based estimates for the bulk of the distribution, but they are enormously valuable in capturing what has been happening right at the top.

Table 3 shows how the share of total (gross) income going to the top 1\% changed between 1980 and 2007, just before the global financial crisis struck. The share going to the top went up in most of these countries over this period, but by a great deal more in some than in others. On the basis of the initial estimates available at that time, Atkinson and Piketty (2007) highlighted a contrast between the English-speaking versus continental European countries, with the former seen as having much larger increases. This contrast is not quite as stark with the estimates available now, though the scale of the increase is clearly greatest for the UK and the USA at almost 9 percentage points, with Canada the next-largest approaching. Australia and Ireland

\footnotetext{
${ }^{1}$ Estimates on a post-tax basis have been produced in separate studies for a few countries.
} 
had lower but still large rises, as did Portugal and Sweden. Finland, France, Germany, Italy, Japan, Korea, Norway and Spain saw lower but still substantial increases. The share of the top $1 \%$ rose but by less than 3 percentage points in the Netherlands, Switzerland, and New Zealand. This leaves Denmark as the only country where this share rose by less than 1 percentage point over that period.

Table 3 also includes the latest available estimates at time of writing, and the year to which these apply. These generally show either stability or some decline in the top $1 \%$ share at the onset of the economic crisis, with a marked fall in Canada, Spain and the UK. This reflects the impact of the economic and financial shock on profits, top executive reimbursement, and the financial sector in particular. It is noteworthy though that in the case of the USA, although the share of the top $1 \%$ fell quite sharply at the onset of the Crisis, it was back to its pre-Crisis level by 2014 . 
Table 3: Top 1\% Shares in Selected OECD Countries, 1980 Onwards

\begin{tabular}{lccccc}
\hline & 1980 & 2007 & $\begin{array}{c}\text { Change 1980- } \\
2007\end{array}$ & Latest Value & Latest year \\
\hline Australia & $\%$ & $\%$ & Ppt & $\%$ & \\
Canada & 4.61 & 9.09 & +4.48 & 9.10 & 2014 \\
Denmark & 8.88 & 15.63 & +6.75 & 13.62 & 2010 \\
Finland & 5.47 & 6.12 & +0.65 & 6.41 & 2010 \\
France & 4.32 & 8.26 & +3.94 & 7.46 & 2009 \\
Germany & 8.17 & 11.69 & +3.52 & 10.80 & 2014 \\
Ireland & 10.72 & 14.04 & +3.32 & 12.98 & 2011 \\
Italy & 6.65 & 11.64 & +4.99 & 10.50 & 2009 \\
Japan & 6.90 & 9.86 & +2.96 & 9.38 & 2009 \\
Korea & 8.36 & 11.35 & +2.99 & 10.44 & 2019 \\
Netherlands & 7.47 & 11.28 & +3.61 & 12.33 & 2012 \\
New Zealand & 5.85 & 7.57 & +1.72 & 6.33 & 2012 \\
Norway & 5.65 & 7.83 & +2.18 & 8.09 & 2014 \\
Portugal & 4.60 & 8.54 & +3.94 & 7.80 & 2011 \\
Spain & 4.32 & 9.77 & +5.45 & & \\
Sweden & 7.63 & 11.24 & +3.61 & 8.58 & 2012 \\
Switzerland & 4.13 & 9.95 & +5.82 & 8.73 & 2013 \\
United Kingdom & 8.40 & 10.91 & +2.51 & 10.62 & 2010 \\
USA & 6.67 & 15.44 & +8.77 & 13.88 & 2014 \\
\hline
\end{tabular}

Source: World Wealth and Income Database

Alongside inequality in income, increasing attention has also been paid to the distribution of wealth among households and whether that has been increasing especially following the publication in English of Thomas Piketty's Capital in the $21^{s t}$. Century, which highlighted what he sees as the return of 'patrimonial capitalism'. The evidence about the distribution of wealth among persons is more limited than for income, but has been improving in recent years, including via new households surveys of assets and debts coordinated by the European Central Bank, and compilations brought together by the OECD and the Luxembourg Wealth Study. This has allowed for more meaningful comparisons across rich countries, highlighting that the distribution is substantially more unequal for wealth than income. One way of illustrating this is that the share of wealth held by the top $1 \%$ of wealth-holders is often as large as the share of income going to the top $10 \%$ of earners. Another is that the Gini coefficient for household wealth in OECD countries is often to be seen in the range 75-85, compared to 40-50 for pre-tax or 25-35 for post-tax income inequality. The ranking of countries by wealth inequality is also not identical to that by income 
inequality. The UK, at least by these measures, has an intermediate level of wealth inequality, despite relatively high income inequality. The Netherlands and Germany, on the other hand, have intermediate inequality in income but relatively high inequality in wealth. The US, however, is again an outlier - households in the top $10 \%$ of the wealth distribution hold $75 \%$ of net wealth there, against $50 \%$ in the OECD average.

The extent to which change over time in wealth inequality can be measured consistently is more limited. The available evidence does not suggest, however, that the pronounced increase in wealth inequality seen over recent decades in the US, and much-commented on there, has been the general experience. As Table 4 illustrates, there appears to have been some increase in share of wealth going to top since the late 1980s in Finland, Italy and the UK, but not for Germany, the Netherlands, Norway or Sweden. As far as the impact of the crisis and recession is concerned, these would be expected to have a marked immediate effect on the value of different assets, including housing and shares, but the pattern across countries appears quite varied, with some increase in inequality in the distribution of wealth in for example Italy and the Netherlands but little or none in the UK.

Table 4: Trends in Wealth Inequality from Late 1980s: Top 1\% Share

\begin{tabular}{lcc}
\hline & Late $1980 \mathrm{~s}$ & $2007-12$ \\
\hline & $\%$ & $\%$ \\
Australia & 9.7 & $11.4(2010)$ \\
Finland & 16.1 & $22.7(2009)$ \\
France & 17.3 & $23.5(2010)$ \\
Italy & 11.0 & $15.7(2012)$ \\
Netherlands & 20.0 & $19.7(2010)$ \\
Norway & 18.7 & $19.4(2010)$ \\
Sweden & 18.4 & $18.8(2007)$ \\
Switzerland & 33.6 & $38.4(2008)$ \\
United Kingdom & 16.6 & $19.9(2012)$ \\
USA & 24.6 & $39.0(2010)$ \\
\hline
\end{tabular}

Source: World Wealth and Income Database, Chartbook of Economic Inequality 


\section{WHAT HAS BEEN DRIVING INEQUALITY UPWARDS?}

The upward trend in income inequality in many OECD countries over recent decades has given rise to a substantial research literature seeking to understand the underlying driving forces, by the OECD (OECD 2008, 2011, 2015), IMF (Jaumotte et al., 2008, Dabla Norris et al., 2015, IMF, 2017) and academic researchers from a comparative or national perspective. (For example, Salverda et al, 2014, and Nolan et al, 2014, present 30 individual country studies set in a comparative framework, and Nolan, 2018b, has 10 such case-studies.) Without aiming at a comprehensive review, here we highlight key strands and messages from this literature.

This research shows first that increasing inequality in household disposable incomes primarily reflects what has happened to the incomes accruing to households from the market. Wages and salaries account for the bulk of household incomes among working-age adults, so changes in the distribution of earnings at household level are key. Earnings dispersion among individual employees has increased in many rich countries over recent decades, primarily reflecting the widening in economic returns to education and skills.

These changes in the shape of the individual earnings distribution are widely seen to have been very significantly affected by the combination of globalisation and technology. Globalisation, and in particular the entry of China into the global trading system, has opened up rich country manufacturing in particular to intense competition from emerging economies with more lower labour costs, while also making capital much more mobile across borders. Firms are much more 'footloose', willing and able to shift production to where costs are lower, and outsourcing of production has proceeded apace. At the same time, technological advances, notably in information and communication technology, both meant that some jobs could be dispensed with entirely and that global supply chains could be organised in such a way that other jobs formerly embedded in the rich countries could be outsourced much more easily. Some 'hollowing-out' of the occupational structure has been part of this process, though more important in some countries than others (see Autor, Katz, and Kearney, 2006, on the USA, Goos and Manning, 2007, Holmes, 2018, and Christini, Geraci and Muellbauer, 2018, on the UK; and comparatively Goos et al., 2009, 2014; Oesch, 2013; Fernadez-Macias, 2012; Eurofound, 2014). Studies differ in the weight 
assigned to globalisation versus technological change, and views in the research literature have fluctuated over time about which has been more important (see for example Slaughter and Swagel, 1997, OECD, 2011, Autor, Dorn and Hanson, 2013, and Helpman, 2017). Given the extent to which they interact, with one enabling and reinforcing the other, it is not surprising that their effects have proved very difficult to disentangle.

The way such trends in earnings of individual employees impact on the distribution of income among households depends on what happens to employment patterns at the household level. The increasing role of women in the paid labour force has for the most part has served to cushion household incomes from the effects of increasing dispersion among individuals. Chen et al. (2014), for example, conclude that if female labour force participation and earnings patterns had remained static over two decades, household income inequality across 20 OECD countries would have increased by 1 point more on average than it actually did.

While much less important than earnings, income from self-employment and from capital (in the form of rent, interest and dividends) constitute a significant share of total household income. These have also contributed to increasing inequality, having grown in importance over time and become more unequally distributed across households.

The shift in the distribution of factor income from wages to profits has been widespread (see for example Bentolila and Saint-Paul, 2003; Atkinson, 2009; Glyn, 2009; Arpaia et al., 2009; Karabarbounis and Neiman, 2014; ILO/OECD, 2015). Its effects may not be fully captured by household surveys, but analysis of the tax data underpinning top income shares estimates show that income from capital has played a significant role in rising top $1 \%$ shares (see for example Atkinson, Piketty and Saez, 2011). 'Top pay' has been even more important. The way top executives are rewarded also changed markedly, with a much greater emphasis on performance-related pay and share options, resulting in a remarkable ballooning of the ratio of top to median or average pay - spreading more rapidly across countries in a context where labour mobility had increased. The expanded role of finance both facilitated those trends and contributed directly to the growth in top incomes, with a substantial proportion of top earners working in that sector (see for example Atkinson, Piketty and Saez, 2011, for 
an overview, Denk, 2015 for European countries, Piketty, Saez, and Zucman for the USA, Bell and Van Reenen, 2014, for the UK).

De-regulation in labour and product markets is also key to understanding how earnings dispersion has evolved. Policies with respect to minimum wages as well as de-regulation help to explain why low pay often became more prevalent over recent decades. Declining union density and power, and the erosion of collective bargaining, are also important. Changes in the structure of households due to factors such as population ageing and the trend towards smaller household sizes, have also contributed to rising inequality.

Finally, and crucially, the effectiveness of direct taxes and transfers also often weakened over the decades preceding the crisis, particularly during the late 1990s and early 2000s, and direct redistribution not been able to fully offset the increases in market income inequality (Immervoll and Richardson, 2011, OECD, 2011). Social safety-nets sometimes weakened, often privileging pensioners at the expense of working-age recipients while struggling to adapt to increasing levels of low pay and in-work poverty. As far as direct taxes are concerned, top income tax rates were generally reduced from the late 1970s and in some cases taxes on income from capital were reduced even more, both because this was seen as encouraging economic activity and because of the competitive pressures this wave created across countries. Redistributive impact generally increased during the initial stages of the economic crisis from 2008, but from about 2010 weakened or stagnated in most OECD countries as fiscal consolidation measures were implemented and 'automatic stabilisers' reduced as recovery got under way in some countries.

Assigning weights to specific factors in terms of their relative importance in driving trends in inequality is extremely challenging, giving the limited data available and range of potential contributory factors, as brought out effectively in the review by Förster and Tóth (2015). It is also important to stress that neither globalisation nor technological change are properly to be understood as external, exogenous drivers unrelated to the institutional and policy context in which they occur. Globalisation itself was enabled by a set of changes in global trading 'rules of the game', as well as in the way finance and capital flows were regulated; technology change, as Atkinson (2015) and Mazucatto (2015) emphasise, does not occur in a vacuum, but instead is fundamentally influenced by state action both directly and indirectly. In a similar 
vein, globalisation and technology were often accompanied by de-regulation in the labour market, and served to reinforce other factors shifting the balance from labour to capital, including declining union power.

\section{INEQUALITY, GROWTH AND 'SQUEEZED' MIDDLE/LOWER INCOMES}

A core concern about rising inequality is that it may be strongly linked to stagnation in real incomes and living standards for ordinary working families, a 'middle-class squeeze', and growing poverty. Thinking about inequality this way represents a radical departure from the long-standing notion that inequality was key to providing the incentives required to drive work, savings, and investment, and that attempts to lower inequality via redistribution would blunt those incentives and reduce growth Okun's "Big Trade-off" (1975). More recently, there is a growing awareness that inequality may in fact undermine both aggregate growth in the economy and the transmission of that growth to middle and lower-income households. This has particularly been the case in the US, where rising inequality has gone together with stagnating wages and household incomes for much of the distribution from the late 1970s onwards.

The channels through which inequality might serve to undermine overall economic growth have been highlighted by for example Stiglitz, (2012, 2015), Ostry et al, (2014) and Dabla-Norris et al. (2015) from the IMF, and Cingano (2014) from the OECD. Rising top income shares may hold back consumer demand, since rich people save more than those on middle and lower incomes, as emphasised by Reich (2010) and Krueger, (2012). Middle and lower-income households may then borrow beyond their means to maintain consumption, fuelling boom-bust economic cycles (Rajan, 2010, Cynamon and Fazzari, 2016). The shift in managerial reimbursement packages that has played a major part in increasing top income shares has also focused CEOs on short-term earnings targets and higher dividends or shares buybacks, so despite high profits firms are reluctant to invest. Higher inequality may also go alongside and reinforce the capacity of firms and their owners that dominate particular sectors to protect their excess profits and stifle competition and innovation, including via political influence and "regulatory capture" (Stiglitz, 2012).

Greater inequality may also impede the capacity of middle and lower earners to invest in their own education and skill upgrading (Aghion, Caroli, and Garcia-Penalosa 
1999). It may also lead to under-investment in the education of poorer children and increase barriers to socio-economic mobility between generations (as discussed further below). The effects of higher inequality at the political and societal level may also work to impede growth through a variety of channels. High or rising inequality may undermine institutions that are critical for sustained growth, both by increasing the voice of the wealthy and by undermining trust in those institutions in the general population, undermining social cohesion, and affecting political behaviour and democratic processes to create 'political risks' (to which we also return below).

Empirical studies have investigated the overall relationship between inequality and growth across countries over time, mostly encompassing both developed and developing countries (for example Barro, (2000), Voitchovsky, 2005, Ostry, Berg, and Tsangarides, 2014, El-Shagi and Shao, 2017). Focusing on results applying to developed countries, a widely-cited study by researchers at the International Monetary Fund suggested that an increase in the share going to the top drags down growth, and that the scale of redistribution through direct taxes and transfers does not reduce it (Ostry, Berg, and Tsangarides, 2014). OECD (2015) also finds that redistribution through direct taxes and cash transfers does not damage growth. Another OECD study (Cingano, 2014) concluded that if inequality had not grown from 1980 onwards in many OECD countries, real GDP growth would have been considerably greater. Lower inequality has also been found to be associated with spells of growth being sustained for longer (Kourtellos and Tsangarides, 2015). While studies are also now emerging on the specific channels through which inequality may affect growth, these are often for just one or two countries, with the USA the primary focus; the extent to which even robustly identified effects in a US context may be taken to apply elsewhere is a central, open question.

While the relationship between inequality and aggregate GDP growth is what has received most attention in the research literature, from the point of view of ordinary living standards this is by no means all that matters. The median of the household disposable income distribution is increasingly recognised as an important (if partial) indicator of 'ordinary' living standards. Thewissen et al (2018) and Nolan and Thewissen (2018) highlight that rich countries have had widely varying experiences in terms of how inequality and median incomes in real terms have evolved together. There are countries and sub-periods where the median stagnated and inequality rose 
rapidly, but also ones where increasing inequality accompanied rapid growth in the median and others where the median rose only modestly while inequality was stable. The US case, where stagnating middle incomes accompanied rapidly rising inequality for much of the period from around 1980, is not representative of the experience of the rich countries over recent decades. A negative and statistically significant association between the change in the Gini coefficient and median income growth was found when data across rich countries over that period was pooled, but this accounted for only a small proportion of the variation in median income growth. Even including overall economic growth and inequality change in the statistical model, much of the variation in income change at the middle remains to be explained.

Alongside real income growth, there are other ways of thinking about and capturing the notion that 'the middle' has been 'squeezed', for example in terms of income shares going to different parts of the distribution or the proportion within bounds framed vis-à-vis the median. Nolan and Thewissen (2018a) shows that the share of disposable income going to the middle three-fifths of the working-age income distribution declined in the years up to the Crisis in half the OECD countries examined. This was especially marked in the UK and the USA; the pattern through the Crisis itself was more varied. The proportion of working-age households with incomes 'within reach' of the middle, between $75 \%$ and $167 \%$ of the median, was also seen to have fallen in most countries up to the Crisis.

If one's concern is with lower rather than middle incomes, it is important to note that the ranking of rich countries by growth in real incomes towards the bottom - for the tenth percentile of the distribution, for example - by no means always aligns with their ranking by growth in the median. Most countries saw lower incomes lag further behind the median since around 1980, but the extent to which this occurred varied widely across them, and in others lower incomes kept pace with the middle. It would therefore be hazardous to see the median as a robust indicator of 'inclusive growth' in and of itself, if that notion is intended to reflect what is happening to the poor in particular (see Nolan and Thewissen, 2018b).

The balance in national income between wages and profits, and how companies distribute their profits, are particularly important in understanding how much of national income growth is transmitted to households and which households benefit. Only some of national income accrues directly to households, and only some of that is 
captured in household surveys. Understanding this complex relationship, including the 'uncoupling' of the median from GDP in recent years that has been muchdiscussed in the USA in particular, is only now getting the attention it deserves. This has prompted a range of studies and reports focused specifically on the US experience (see e.g. Fixler and Jaditz, 2002; Fixler and Johnson 2014, Jorgenson and Slesnick, 2014, Economic Report of the President, 2015) as well as elsewhere, notably from a joint OECD-Eurostat Expert Group (Fesseau et al., 2013, and Fesseau and Mattonetti, 2013) seeking to reconcile national accounts and household survey-based income aggregates and produce distributional measures consistent with national accounts totals. (That is a goal shared by the Distributional National Accounts (DINA) academic research programme involving Piketty, Saez and colleagues - e.g. Piketty et al., 2018, Alvaredo et al., 2017). Focusing specifically on the GDP-median relationship, Nolan, Roser and Thewissen (2018) found that the scale of the divergence between them over time actually varied greatly across OECD countries, with the US an outlier. The factors contributing to this divergence were also seen to vary a great deal across countries: differing price deflators for producers versus consumers, the gap between mean income as measured in the national accounts versus household surveys, increasing income inequality (reflected in the difference between mean and median income), and declining household size (reflected in the difference between unadjusted and equivalised median income) contributed to the GDP-median gap to differing degrees for different countries.

\section{ECONOMIC INEQUALITY AND SOCIAL 'BADS'}

Among core concerns about increasing inequalities in income and wealth is that these may lead to more divided societies with worse social outcomes across various domains. The substantial body of research across disciplines on this broad topic covers a very wide and diverse range of areas in which such impacts could potentially arise, especially in relation to health and health inequalities but extending to many other social outcomes such as poverty and deprivation, family formation and breakdown, crime and imprisonment, and social capital. This was at the core of Wilkinson and Pickett's widely-cited book The Spirit Level (2010), as reflected in its sub-title Why Equality is Better for Everyone. This argued that physical health, mental health, drug abuse, education, imprisonment, obesity, social mobility, trust and community life, violence, teenage pregnancies, and child well-being are all 
significantly worse in more unequal than in less unequal rich countries. It served to reinforce an already strong stream of research on these topics, of which only a flavor can be given here. We bring out in particular the divergence between what economists versus epidemiologists and public health researchers take this literature to have established with respect to income inequality being a key cause of such outcomes.

\section{Health}

Studies focused specifically on the relationship between income inequality and health now constitute an extensive body of research in itself, with very active debates about the nature of the relationships between income and health, and between income inequality, health and health inequalities. The existence of a strong social gradient in health, reflected in a gradient as one moves up or down the income distribution, is common ground, but this could primarily reflect 'selection', i.e., health determining income, as well as or indeed instead of income determining health. Economists have devoted much effort to teasing out the myriad channels through which health can affect labour market success, income and wealth (summarised in for example O'Donnell et al, 2015). This body of research emphasizes in particular how ill-health in childhood can have a very long reach into constrained economic opportunities in adulthood, by constraining human-capital acquisition through education and skills formation, as well as persistent and delayed effects on adult health (Almond and Currie, 2012; Currie, 2009; Heckman, 2007; O’Donnell et al, 2015). Additionally, other factors - such as education - will influence both income and health status, greatly complicating the interpretation of the bivariate relationship.

While many public health researchers have attributed the health-income gradient to a causal effect running from income to health, economists have been more difficult to convince, generally insisting on longitudinal analysis or quasi-experimental methods to assess causality robustly. As far as adult health is concerned, panel regressions and quasi-experimental studies have had inconsistent, and mostly negative, results: the review by Cutler et al, (2011) concludes that "a preponderance of evidence suggests that in developed countries today, income does not have a large causal effect on adult health" (p. 21). O'Donnell et al (2015) similarly conclude that economists' research has tended to produce evidence indicative of no impact of income on health in adulthood, or effects that are small in comparison to the observed income-health gradient (p. 1498). However, they are careful to note that the methods being 
employed may struggle to capture a relationship that, should it exist, is likely to emerge over a lifetime rather than be observed in the shorter term in response to a change in income. The evidence for an effect of parental income on children's health from such studies is a good deal stronger, as Cutler el al (2011), conclude, with higher income being protective of child health; they also stress that such differences in health in childhood may themselves continue to cumulate later on.

If health does depend causally on income, then differences in income will generate differences in health, representing one route through which the distribution of income could affect health outcomes. A distinct hypothesis, though, is that the health of an individual is contingent not only on his or her own income but also on the degree of economic inequality within the society as reflected in the distribution of income. This has adherents in the field of public health in particular. A range of studies has documented the correlation between income inequality and health across countries and across US states in particular (as documented in Pickett and Wilkinson, 2015). The core underlying mechanism postulated is that feelings of subordination and lack of control produce psychosocial stress that serves to raise mortality from all causes, cardiovascular disease and infectious disease. Hierarchy-based explanations for the income gradient are the subject of a voluminous literature, with the various mechanisms potentially involved summarised by Wilkinson and Pickett (2018). However, a consensus has not emerged on whether rank matters, or whether the distance across ranks - the degree of inequality - matters as well. Pickett and Wilkinson (2015) conclude from their review of available studies that "The body of evidence strongly suggests that income inequality affects population health and wellbeing”. (p. 1). By contrast, O'Donnell et al's (2015) review from an economist's perspective concludes that "There is little credible evidence to support the claim that the economic inequality in society threatens the health of all its members or that relative income is a determinant of health" (p. 1420). In a similar vein, Cutler et al's (2011) conclusion is that "whether or not relative income matters for health, there is little evidence that it drives aggregate correlations between income inequality and population health" (p. 24).

This striking divergence reflects differing interpretations of the available evidence, the inherent difficulties in establishing causal relationships of this complex and longterm nature, and also disciplinary differences in what would be regarded as 
convincing evidence of causation. ${ }^{2}$ As in efforts to identify causal effects of inequality more broadly, it is difficult to reach strong conclusions about the impact of inequality by simply comparing countries at a point in time, since countries also differ in many other respects, including ones with which inequality is correlated that might well affect health/social outcomes (for example, the reach and generosity of welfare state service provision). Looking at what has happened to outcomes as income inequality has increased over time offers one promising approach. Leigh et al (2008) conclude that most such studies find no statistically significant relationship over time, though they caution that confidence intervals are often wide: "this is a field with too many theories for the number of available data points" (p. 399). Focusing on one specific but important example, the United States, Truesdale and Jencks (2016) note that it saw relatively small increases in life expectancy at birth between 1950 and 1970, when income inequality was falling, and much larger increases between 1970 and 1990, when inequality rose rapidly. (It is worth noting that the recent upturn in mortality for certain socio-demographic groups in the US highlighted and characterised by Case and Deaton (2017) as "deaths of despair" are attributed by them to a broad deterioration in the lives of Americans without a college degree who entered adulthood after 1970; increasing income inequality is an important part of the context in which this deterioration has taken place, but it is much broader than that.)

Widening inequalities in mortality among different population sub-groups could be one factor contributing to slowdown in life expectancy improvements at national level, and would in any case be of serious concern in themselves. A recent OECD study (Raleigh, 2019) points to evidence that the causes of the slowdown in mortality improvements are having greater impact in more deprived areas in the UK, whereas in Canada gains in life expectancy over time have been uniform over the earnings distribution, with equal improvements for high and low earners. Truesdale and Jencks (2016) note that in the United States, disparities in life expectancy by income increased sharply among both men and women from the 1980s. However, they are cautious in interpreting such patterns: "It seems reasonable to suspect, but very difficult to prove, that rising income inequality played a role in exacerbating SES

\footnotetext{
${ }^{2}$ A recent report (Mackenbach et al, 2018) from an expert committee established by the Federation of European Academies of Medicine and the European Federation of Academies of Sciences and Humanities highlighted that the lack of scientific consensus on causal mechanisms underlying health inequalities is partly due to a lack of consensus across disciplines on research methodologies.
} 
(Socio-Economic Status) related gaps in mortality" (p. 422). Drawing on available information across rich countries over recent decades, they find no relationship between changes in disparities in mortality (by education and occupation) and either levels of income inequality for earlier periods or recent changes in income inequality. However, they caution that most theories about how income inequality affects health imply that the lags are likely to be long and variable, and it may not possible to detect such effects with the data currently available; in a similar vein to other recent contributions, they point to further investigation of specific mechanisms whereby income and its distribution may influence health as the priority for research.

\section{The family}

Turning to other social outcomes that feature in research about the impact of rising inequality, one is family formation and breakdown, and in particular the notion that higher/rising income inequality may be driving higher rates of teenage pregnancy, lone parenthood, and divorce - a topic which generates much political and popular debate and the occasional bout of 'moral panic'. Cherlin (2018), for example, argues that rising income inequality has been an important driver of changes in the formation and dissolution of US families: "the prima facie case that inequality - and more specifically the diverging labor market opportunities for the highly-educated and the moderately-educated - has driven family formation and dissolution seems strong for the United States". ${ }^{3}$ Fertility is another element in the picture, with a substantial literature on the role of institutions and policies in influencing fertility (see for example Björklund 2006).

In a valuable comparative analysis Calvert and Fahey (2013) look at these together, focusing on 13 aggregate indicators, half relating to partnership (e.g. divorce rate, percentage of children living with lone parents, percentage of births outside marriage) and the other half to fertility (e.g. teenage birth rate, abortion rate, incidence of large families, total fertility rate). They find only one of these to have a significant positive correlation with the contemporaneous level of income inequality in the country as captured by the Gini coefficient, the exception being the teenage birth rate which is higher in more unequal countries. Many of these indicators were also seen not to be characterised by a distinct social gradient consistently across countries.

\footnotetext{
${ }^{3}$ https://ifstudies.org/blog/how-economic-inequality-drives-family-formation-and-dissolution
} 
As far as trends over time are concerned, Calvert and Fahey highlight that that the 'second demographic transformation' - involving decline in fertility, instability of partnership, the transformation of women's role and the decoupling of sex from marriage - occurred for the most part when income inequality were falling or already at an all-time low in the 1960s and 1970s. Even for the USA, Kenworthy and Smeeding (2013) note that the fertility rate there fell sharply in the 1970s but then levelled off while income inequality continued to rise, the decline in the marriage rate predates the rise in income inequality, divorce increased sharply in the 1970s but declined subsequently, and while lone parenthood has risen steadily, that began in the 1960s well before income inequality began to increase, and slowed from the 1980s. Comparatively across the rich countries, Calvert and Fahey's overall conclusion is that apart from its current association with teenage births, income inequality does not exert a consistent effect on family behaviour and is not a major contributor to differences between countries or changes over time, trends in income inequality explain little of the dramatic changes in family life seen in many rich countries in recent decades.

\section{Crime}

The notion that higher income inequality is associated with more crime and violence is also common though difficult to assess empirically not least in light of the variability in crime statistics across countries and over time. There is evidence for a relationship between income inequality and levels of violent crime, in particular homicide; reviews by Pridemore and Trent (2010) and Rufrancos et al. (2013) highlight the correlation between levels of income inequality and homicide rates across countries (on which see also Hsieh and Pugh, 1993, Daly, Wilson and Vasdev, 2001; Fajnzylber, Lederman and Loayza, 2002). Both psychosocial and material factors are seen in this literature as playing a mediating role. Focusing on trends over time, a review of time-series and panel studies by Rufrancos et al., (2013) also found a significant increase in the murder rate with rising income inequality. As far as crime more generally is concerned, though, recent years have seen substantial and sustained reductions in recorded crime in the USA as income inequality continued to rise (see Kenworthy and Smeeding, 2013). What has been termed the 'great American crime decline' began in the early 1990s and ranged across all regions, all crime types, all 
demographic groups and all socio-economic strata (Blumstein and Wallman, 2000; Zimring, 2007). This picture is replicated in some cross-national studies, with Tseloni et al. (2010) in their analysis of trends in criminal victimisation referring to the 'universal nature of the crime decline'. Income inequality is clearly only one of a complex set of factors underpinning variations in crime across countries and over time.

Patterns of punishment bear a rather clearer relationship to income inequality and welfare regimes. Kilcommins et al., (2004) found that 'countries with well-developed, universalistic, generous welfare regimes tend to have lower prison populations than those with low levels of welfare provision' (p. 278); other studies arriving at similar conclusions are Cavadino and Dignan, (2006); Enzmann et al., (2010); Lacey, (2008). In an authoritative review, Lappi-Seppala (2008) observed that "Looked at globally, increased income inequality seems to produce more prisoners." (p. 252) The strength of this relationship is noteworthy. Healy et al. (2013) also report that levels of tolerance are significantly correlated with inequality, public attitudes towards recidivist burglars are substantially more punitive in societies characterised by higher levels of inequality, and a significant positive relationship between fear of crime and inequality was also found to exist; increases in the prison population may reflect such attitudes and changes in penal policies more than the level of crime itself.

\section{Poverty}

Poverty, deprivation and social exclusion may also be seen as distinct social outcomes that may be at least partly driven by income inequality, though they are clearly closely intertwined and may be better seen as joint products of underlying socio-economic forces and structures. If the poor are identified as those below a particular proportion of average or median income in the country in question, there is a reasonably high cross-sectional correlation between the extent of poverty and the level of income inequality among rich countries, though the poverty rates of countries with a similar level of income inequality still vary significantly (see for example Nolan and Marx, 2009). In terms of trends over time, such relative poverty measures have often risen with overall inequality, though the relationship is weaker than when comparing levels in a single year, with inequality trends also reflecting what has been happening in the top half of the distribution (see for example OECD, 2008; Nolan, 2018; Hills et al, 2019). For the UK, Hills et al (219) report that over the last fifty years there is a clear 
positive empirical association between income inequality and relative income poverty: years with comparatively low inequality had lower relative poverty, and those with high inequality had higher poverty rates.

When poverty is instead thought of in 'absolute' terms and measured vis-à-vis income thresholds fixed in purchasing power terms, OECD (2008) documents that even countries where relative income poverty increased between the mid-1990s and mid-2000s saw significant reductions in such an anchored poverty measure. Analysing recent European experience, Hills et al (2019) found that increasing inequality implies a slower reduction (or faster increase) in poverty against such a fixed income standard. However, the major factor accounting for change over time is what happens to average income levels, with changes in income inequality generally playing a much more modest role (Nolan and Whelan, 2014). Similarly, indicators of material deprivation and multi-dimensional poverty also display significant associations with levels of inequality in different European Union countries, but over time are much more strongly related to how average household income varies (Calvert and Nolan, 2012; Hills, 2019), though in some rich countries where mean income fell sharply in the economic crisis, the impact on the poor was exacerbated by rising inequality.

\section{Intergenerational mobility}

The final social outcome which has featured strongly in debates about the impact of rising income inequality is intergenerational mobility. The idea that intergenerational mobility is lower in countries with high inequality was highlighted in the so-called 'Great Gatsby curve' popularised by Alan Krueger, drawing on Corak (2012). This captures what appears to be a common-sense notion that, as Andrews and Leigh (2009) put it, "Moving from rags to riches is harder in more unequal countries". This could operate via a variety of channels, including widening gaps in parental spending on their children's human capital acquisition broadly conceived, as well as increasing spatial segregation affecting social networks and future prospects. Much of the evidence put forward to support such a relationship (including the Great Gatsby curve itself) is based on comparing countries at a point in time, from which it is hazardous to draw strong conclusions. Even the strength of that cross-sectional relationship depends on which countries are included and on whether mobility is being assessed in terms of earnings, household incomes or social class position (see for example Bukodi 
and Paskov, 2018; OECD, 2018). Seeing what happens to mobility as inequality increases markedly is a more promising route to identifying its distinct effects, but so far evidence of that sort provides a mixed picture. Some US studies suggest that earnings mobility has declined as inequality increased (Aaronson and Mazumder, 2008) but others conclude it has remained unchanged in recent decades (Lee and Solon, 2009; Chetty, Hendren, Kline, Saez, Turner, 2014). For the UK, Blanden et. al. (2001, 2004) found a stronger association between earnings and family income at age 16 for a cohort born in 1970 than one born in 1958; this has been the subject of debate in terms of data quality and the contrasting picture when social class is examined (see Erikson and Goldthorpe, 2007, Goldthorpe, 2013, 2016, Blanden, Gregg and Macmillan, 2013). For France, Lefranc (2011) found reduced mobility for those born from the end of the 1950's onwards, and for Finland Pekkala and Lucas (2005) also found that it may have worsened. For Australia, Leigh (2007) found no significant change over recent years, Heidrich (2015) came to a similar conclusion for Sweden, as did Lefranc et al (2014) for Japan and Pekkarinen et al (2017) for Norway. Findings also often vary depending on the basis on which ranking/mobility is being assessed. These developments do not seem particularly well-aligned with the evolution of income inequality in these countries, though the rapid increase in inequality over recent decades may not have worked its way through as yet to observed earnings or incomes for the next generation.

These studies, like most of this literature, focus on mobility in relative terms, but 'absolute' change in terms of real incomes from one generation to the next may also be central to how mobility is felt. Chetty et al's (2016) finding for the US that around 90\% of children born in 1940 earned more than their parents, but that this had fallen to $50 \%$ for those joining the labour market in the recent years, has been widely quoted. This decline was largest for children whose parents were in the middle of the distribution (the "middle class"). Corresponding results for most other rich countries would probably paint a more positive picture, given the distinctively limited growth in real wages in the US from the late 1970s.

Other important recent contributions by Chetty and co-authors compare areas within the US and concludes that intergenerational mobility is lower in areas with greater income inequality (Chetty, Hendren, Kline, Saez 2014; Chetty and Hendren, 2016). The effects of economic inequality on mobility were found to be mediated by high 
residential segregation, low quality of school and social capital in the area, though the impact of inequality remained when these were incorporated into the analysis. (The paper by Corak in this issue provides an in-depth discussion of the spatial perspective on mobility.)

\section{INEQUALITY AND POPULISM}

We turn finally to the impact that rising inequality may have on politics, and specifically on the recent rise of populism, widely discussed in the research literature (e.g. Heinö, 2018; Kyle and Gultchin, 2018; Rodrik, 2018) and commentary. As well as having intrinsic value, political stability, social cohesion and the legitimacy of democracy have been recognised as helpful for economic growth (e.g. Alesina and Perotti, 1996; Acemoglu et. al. 2019). The relationship between the economic and political spheres is complex and dynamic, with economic institutions and outcomes shaping and being shaped by political institutions and outcomes (Robinson et. al., 2005). The diverse channels through which economic inequality may affect the political sphere are themselves extremely complex. Some are relatively direct (e.g. inequality affecting trust and social cohesion), while others operate through several layers (e.g. inequality altering political access, which shapes public policy, and can then undercut the legitimacy of the political system). Some relate more to the perceptions of inequality (e.g. trust) and others to inequality itself (e.g. political access). Since space does not allow us to adequately cover the relationship between inequality and politics more broadly, we focus on the much-discussed potential connection between inequality and the rise in populism, and the channels by which that could be mediated. (For a survey with more emphasis on other political dimensions, see Glaeser, 2008). The factors underpinning the recent rise of populism in advanced economies are multidimensional, but some authors highlight mainly economic factors (e.g. Guiso et. al., 2018) while others give more prominence to cultural factors (e.g. Inglehart and Norris, 2016). ${ }^{4}$ Here, we focus mainly on aspects that can be, directly or indirectly, linked to inequality, while noting other potential drivers.

\footnotetext{
${ }^{4}$ The definition of populism itself is rather fluid; as the Economist magazine pointed out in 2016, current usage can encompass militarists, pacifists, admirers of Che Guevara or Ayn Rand; tree-hugging pipeline opponents or drill-baby-drill climate-change deniers. Populism is commonly regarded as combining an anti-establishment perspective with authoritarianism and nativism (see for example Mudde, 2007). It sees common people as exploited by a privileged elite, and seeks to address this, perhaps via a charismatic leader appealing to the masses and sweeping aside existing institutions. This is clearly difficult to implement empirically in studying voting behaviour.
} 


\section{Trust}

One of the factors often cited as underpinning populism is the erosion of trust in institutions (e.g. political parties) and in others members of society. For instance, Dustmann et. al. (2017) use the European Social Survey (ESS) to show that individuals who vote for left or right wing populist parties have little trust in both national and European institutions. While the evidence does suggests declining levels of trust for many countries (e.g. ERCAS, 2015; Gould and Hijzen, 2016), there is no empirical consensus regarding how much these changes are related to inequality, partly reflecting the different methodologies, data sources, periods and set of countries used. ${ }^{5}$ On the one hand there are studies like Barone and Mocetti (2016), who use data from the World Values Survey from 1981 to the mid-2000s for 27 advanced economies and find a decline in the share of individuals who think 'most people can be trusted' to be statistically associated with increasing income inequality. Similarly, Gould and Hijzen (2016) find that much of the observed decline in trust in the United States between 1980 and 2000 is due to increased wage inequality. Other studies showing that inequality erodes trust include Beugelsdijk and van Schaik (2005), Dincer and Uslaner (2010), Horvath (2013), Uslaner and Brown (2005) and Zak and Knack (2001).

On the other hand, some studies do not find a link between inequality and trust in others. Stein and Lancee (2011), for instance, find that such link disappears when the level of national wealth is taken into account (suggesting the availability of resources is more relevant that their distribution). Olivera (2015) also finds the link disappears when moving from a cross-country to a fixed effects regression methodology. ${ }^{6}$

Inequality has also been linked to lower trust in government, supranational institutions and democracy (e.g. Dragolov et. al. 2016). ${ }^{7}$ Gould and Hijzen (2016) find

\footnotetext{
${ }^{5}$ There are several channels by which inequality might undermine trust, including erosion in social ties (which affects the degree of cooperation and transaction costs in economic interactions among private individuals, not only for domestic transactions but also for international trade), perceptions of unfairness, envy, and enhanced conflict over resources. For a review of the literature on the topic, see Jordahl (2009).

${ }^{6}$ Uslaner (2016) criticises the methodological change in Olivera (2015), partly because fixed effects are well suited to study relationships only when variables change significantly over the studied period. He suggests the change in inequality and trust was not strong enough for fixed effects to identify the link.

${ }^{7}$ Social solidarity, in the sense of concern for and willingness to help others, has also been seen in some studies as negatively related to inequality, though that relationship is not strong and a variety of other factors appear to be at work (e.g. Paskov and Dewilde, 2012).
} 
suh a link for trust in government. Inequality may partly explain the rise in Euroscepticism, with a widening gap in anti-EU sentiments between individuals with low and high levels of education (Kuhn et. al., 2013). To the extent that greater inequality of opportunities translates into higher educational gaps among individuals, Euroscepticism can certainly be indirectly linked to inequality. Furthermore, Andersen (2012), using data from the World Value Survey for 35 (mostly advanced) economies, found that countries with higher income inequality had lower support for democracy across the income spectrum. However, several studies link the observed fall in trust to economic factors other than inequality per se. For instance, Guiso et. al. (2018) uses the ESS to show that economic insecurity (measured in different ways, such as employment status, perception of income difficulties, exposure to globalisation, and so on) lowers trust in political parties (and is a significant driver of voting for populist parties). Foster and Frieden (2017) also find economic factors, particularly unemployment, explain changes in trust in government among European individuals. As such, part of the decline in trust might well be episodic, reflecting adverse economic shocks like the Great Recession (e.g. Algan et. al. 2017), rather than longer term trends in inequality.

\section{Political representation}

Populism is more likely to arise where democracy has less legitimacy. As Urbinati (2019) states, populism "exploits the perception that parliamentary and party politics fail to provide adequate representation for some key portions of the population (Norris 1997); it questions electoral or mandate representation because of the gap it creates between the people as the principle of legitimacy and the people as an actual social reality, and thus between the electors and the elected. Populism wants to fill that gap" (page 6.3). Thus, factors undermining democratic representation might contribute to the rise of populism.

Perhaps the most basic dimension of political representation is political participation among citizens, e.g. voter turnout which has fallen in advanced economies (e.g. OECD, 2019). This might not be surprising, given the decline in trust in others, public institutions and democracy itself: Guiso et. al. (2018) pin-point the connection between trust in political parties and electoral participation in Europe. Various studies have shown that falling political participation seem to be concentrated particularly 
among low income, less well educated, cohorts. For instance, Jaime-Castillo (2009) shows that, in a variety of elections in the 2000s covering 23 OECD countries, income (and education) is directly related to electoral participation. In the United States, those in the bottom income quintile were $25 \%$ less likely to vote than those in the top income quintile. He also finds a direct negative effect of inequality (particularly of inequality at the top) on electoral turnout. Solt (2008) also finds that political participation is negatively affected by inequality, the impact being greater the lower the quintile to which the individual belongs. Horn (2011) also finds a negative link between inequality and voter turnout in the 2009 European Parliament election, while Solt (2010) shows that the average predicted probability of voting across U.S. states declines as the Gini of the state increases. As Parvin (2018) summaries the findings in the literature, "[b]roadly speaking, the more socially and economically unequal a society is, the less politically engaged is its citizen body, and the poorer one is relative to others in society, the less one will participate." (p.34) ${ }^{8}$

The degree of representativeness of the political system can be seen more directly by comparing the preferences of voters with those of politicians (sometimes called a 'congruence analysis'). For instance, Belchior (2013) analyses candidates from 189 political parties in 27 European countries for European Parliament elections, and finds that MEPs are ideologically more extreme than voters. Lesschaeve and Bernhard (2013) highlight that MEPs' preferences regarding European integration are shaped not only by that of their party and voters, but also by businesses. Barber (2016) studied the congruence in ideology between voters, candidates and donors in the US for the 2012 general election, and their key results are illustrated in Figure 1. The leftpanel shows that senators Democratic senators are more liberal and Republican senators more conservative than most of their voters. By contrast, the right-panel

\footnotetext{
${ }^{8}$ Inequality seems to have consequences not only for electoral participation but also for civic and social participation. Lancee and Van de Werfhorst (2012) focus on this for 24 European countries, defining civic participation in terms of involvement in formal organisations like charities, political parties, professional groups, etc, and social participation in terms of interaction with family and friends. They find that higher inequality lowers civic participation among the less well-off, whilst increasing civic participation among the better-off. Regarding social participation, it is mainly the poor who become socially disconnected when inequality increases. Uslaner and Brown (2005) point to similar negative effects of inequality on trust and of trust on activities like involvement in political parties, charitable donations and volunteering, for the United States.
} 
shows that senators across both parties are very much aligned with the ideology of their donors, who constitute less than $5 \%$ of the electorate.

Figure 1: Ideological Distance Between Voters and Senators, and Donors and Senators, 2012 general election, United States
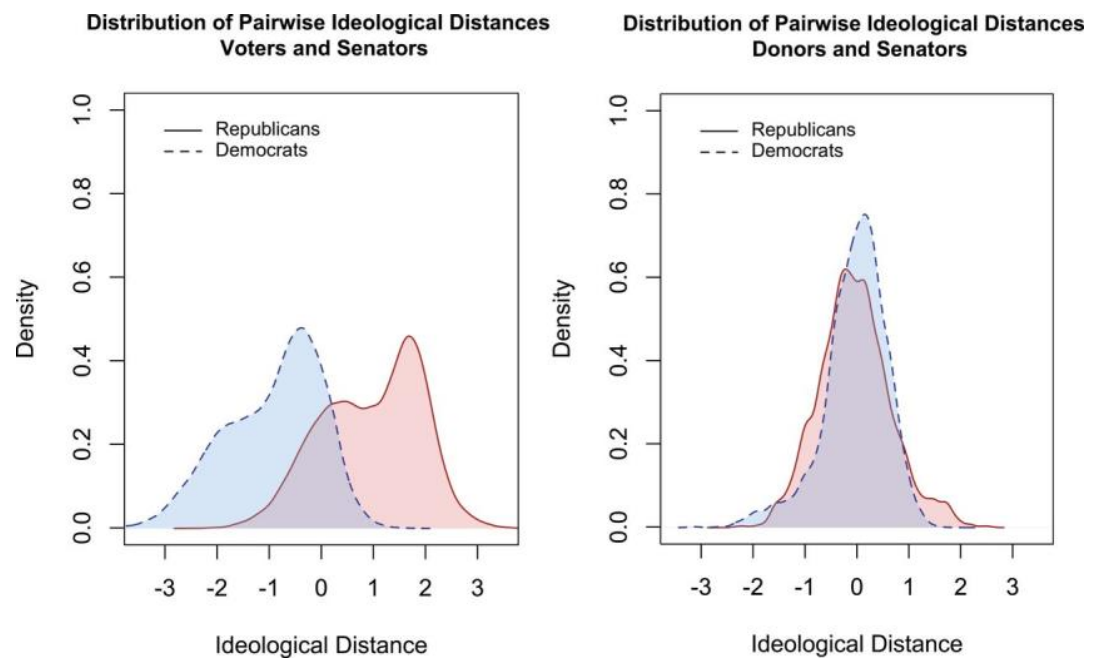

Source: Barber (2016).

More broadly, Gilens (2012) provides comprehensive evidence that US government policies are much more responsive to the political preferences of people from more wealthy backgrounds, with the preferences of the great majority of U.S. citizens having little impact. Richer individuals are not only more likely to vote, but are also more active in terms of lobbying activities, active party participation, and campaign financing (e.g. Brady, Schlozman and Verba, 2012; Gilens, 2012; Page, Bartels and Seawright, 2013). In the US, the proportion of contributions to political parties coming from the top $0.1 \%$ grew from $19 \%$ in 2000 to $29 \%$ in $2014 .{ }^{9}$ Such strong ideological congruence is then partly reflecting the close relation between money and politics.

Given these patterns, as inequality increases (particularly in terms of top income shares), the relative capacity of richer individuals to finance political campaigns, parties, and lobbying activities grows, ceteris paribus. This may help shift political policies in favor of the interests of the wealthy. While this may be particularly likely $n$ the US, given the way political activity is funded there, there is also some suggestive evidence for other rich countries. Epp and Borghetto (2018) study the direct

\footnotetext{
${ }^{9}$ For details, see https://www.opensecrets.org/news/2015/04/the-political-one-percent-of-the-onepercent-in-2014-mega-donors-fuel-rising-cost-of-elections/
} 
relationship between income inequality and the political agenda for nine European countries, between 1941 and 2014. Their results suggest that a higher Gini index is associated with a political agenda tilted more towards law and order, national defense, and immigration, and not with policies that might reduce inequality.

\section{Other drivers of populism}

We have discussed how rising inequality may fuel populism by eroding trust and undermining democratic representativeness, providing a breeding ground for the emergence of anti-establishment movements. Research has also highlighted other factors, cultural and economic, as potential drivers of recent populism waves, and these should also be noted. Inglehart and Norris (2016) use data from the 2014 Chapel Hill Expert Survey to identify the ideological location of political parties in 31 European countries, finding on this basis that votes for populist parties across many countries roughly doubled in recent decades. They then employ pooled European Social Survey data from 2002-2014 to examine who votes for populist parties. Socioeconomic variables have some explanatory power, but much less than cultural attitudes. Economic insecurity plays a role, but explains less of the rise in support for populist parties in Europe than cultural backlash - "retro reaction by oncepredominant sectors to progressive value change". The fact that support for populist parties has risen in countries where inequality has been fairly stable over time (such as Austria and France) as well as ones where inequality has risen, and in countries where income growth has been quite robust (such as Poland) as well as ones where median incomes have stagnated, illustrates the complexity of the factors at work. This is highlighted by the differing political reactions to particularly severe crises in the Great Recession in Ireland, Portugal, Greece and Spain.

In the United States, such "retro reaction by once-predominant sectors to progressive value change" has also clearly played an important role alongside rising inequality and stagnating real incomes for much of the distribution over a long period. The white working-class population whose livelihoods have been negatively affected through decades of manufacturing decline provided the core constituency supporting Donald Trump, but economic dysfunction combines with cultural and demographic factors in a way that makes them very hard to disentangle. 
Unequal economic gains and losses from globalisation within advanced countries have also been highlighted as a driver of populism. There is some recent evidence of specific effects of globalisation on political outcomes in the case of the 'China shock', China's emergence as a major export economy. Autor, Dorn, Hansen and Majesi (2017) find that congressional districts exposed to Chinese imports disproportionately removed moderate representatives from office in the 2000s and replaced them by more extreme candidates. Their conclusion is that Hillary Clinton would have been won Michigan and Wisconsin if the trade shock from Chinese imports had been $25 \%$ smaller, and would have won Pennsylvania and the presidential election if it had been $50 \%$ smaller. Dippel, Gold, Heblish (2015) find an increase in support for extremeright parties in Germany (but not for extreme-left parties), also in connection with the 'China shock' (plus trade exposure to Easter Europe), with almost two thirds of the total rise in extreme-right vote share attributed to labour market adjustments, including changes in employment shares in manufacturing. Malgouyres (2017) links the vote share for the National Front in France to local exposure to import competition from low-wage countries (not only China). Relatedly, Colantone and Stanig (2018a) finds that regions in the UK more exposed to trade with China voted more strongly in favour of leaving the EU. Colantone and Stanig, (2018b), extends this analysis to 15 European countries for the 1988-2007 period, finding again a significant effect of the 'China shock' on support for populism parties.

The study by Guiso et. al. (2018) noted earlier differentiates between the "supply" and "demand" for populism. Regarding the former, they show that, as populist parties become electorally more successful, other parties shift their political position towards populism. Regarding the latter, they find that economic insecurity has been a significant driver of the "demand" for populism (in terms of voting preferences). They also link negative attitudes toward immigration with preferences for populism, albeit they suggest this is a channel rather than a cause, which they link back to economic insecurity. Algan et. al. (2017) in a study of European regions also find that greater economic insecurity (proxied by increase in regional unemployment) increases voting for extremist parties and leads to more hostile views toward immigrants, with little support for cultural-driven immigration backlash. Colantone and Stanig (2018a) also find that the strengthening of anti-immigration sentiments in the UK is partly due to 
strong import competition from China, suggesting again an economic origin of cultural changes often associated with populism.

\section{Trump and Brexit}

The election of Donald Trump as US President and the UK vote for Brexit in 2016 are often seen as quintessential examples of a populist reaction to rising inequality, but research suggests a much more complex picture. Voting patterns reveal that characteristics such as being white, unemployed (and particularly white unemployed), evangelical Christian, self-identified as American, and of low income and education are usually found to be strong predictors of having voted for Trump (e.g. Irwin and Katz, 2016; Pastor and Veronesi, 2017). This highlights the potential importance of both economic and cultural factors. Darvas and Efstathiou (2016) directly test the relation of inequality with voting patterns at the state and county level. After controlling for other characteristics, they find a significant effect of higher income inequality in both the level and change in Trump's support. In a narrative analysis of the economic changes in U.S. from Ronald Reagan to Barrack Obama, Komlos (2018) concludes that "[t]ax cuts, trickle-down economics, deregulation, globalization, and NAFTA were all portrayed as great strides forward. All were supposed to make us richer. Instead, they conferred most of the financial benefits on only one social strata: the ultra-rich, but led to the "hollowing out" of the middle class." He argues that these changes, which drove up inequality, also underlie the rise of Trump. This brings out that rising inequality and populism/support for Trump may be best seen as the joint product of such underlying forces, rather than as a linear relationship with inequality as the driver. In such a framing, other economic factors may also be important. Autor et. al. (2017) find import competition from China to be significant in explaining swings toward populist candidates (like Trump) in 2016. More broadly, Bor (2017) finds that counties in which life expectancy stagnated or declined between 1980 and 2014, characterised by increased economic insecurity, the emergence of the opioid epidemic, and relatively poor access to medical care, saw an increase in the Republican vote share between 2008 and 2016.

In contrast, Rothwell and Diego-Rosell (2016) suggest unemployment, exposure to import competition or immigration are less important in predicting support for Trump than other socioeconomic factors such as "living in racially isolated communities with worse health outcomes, lower social mobility, less social capital, greater reliance on 
social security income and less reliance on capital income”. Schaffner, Macwilliams and Nteta (2018) find that about two-thirds of the gap between white voters with and without college degree in support for Trump in 2016 was due to attitudes of racism and sexism, with dissatisfaction about personal economic condition playing only a minor role. Green and McElwee (2018) also find racial attitudes among white voters to be an important predictor of Trump support, although local economic distress factors are associated with lower voting by non-whites. Mutz (2018), using panel data for 2012 and 2016, suggests that is not being 'left behind' in the past that matters, but rather anxiety among dominant groups (white, Christian, male) about their future status: "[t]hose who felt that the hierarchy was being upended - with whites discriminated against more than blacks, Christians discriminated against more than Muslims, and men discriminated against more than women - were most likely to support Trump.” (page E4338). Major, Blodorn and Blascovich (2018) find evidence that Trump's explicit anti-immigrant rhetoric and policies had special appeal for white Americans with high racial and ethnic identification. Gimpel (2017) also finds that Trump's anti-immigration emphasis was a significant factor, in comparison with the votes obtained by Romney four years earlier. Smith and Hanley (2018) compare the role of financial stress with prejudices arising from what they call "authoritarianism", defined as "the wish to support a strong and determined authority who will 'crush evil and take us back to our true path."” (page 196). Focusing on white voters, they find that supporting "authoritarianism" is a significant predictor of voting for Trump, whereas income, education, and a measure of financial insecurity are not. Separating the role of economic versus non-economic factors is intrinsically very difficult given the complex ways in which they may interact. Knowles and Tropp (2018), for instance, show that racial diversity at the neighbourhood level increases support for Trump among whites, but this is mediated by their economic situation: a healthy local economy minimises the effect of racial diversity on the level of support for Trump.

Turning to Brexit, overall income inequality (as measured by the Gini coefficient) in the UK increased very sharply in the Thatcher era but not since then, as noted earlier. ${ }^{10}$ Any potential impact of inequality on Brexit must thus come from either a lagged effect or from trends at the local level masked by such aggregate statistics.

\footnotetext{
${ }^{10}$ Conversely, there has been a more or less steady rise in top income and wealth shares since the 1980s (Alvaredo et. al. 2018).
} 
There is a correlation between income and the percentage of votes for Leave at the local authority level (e.g. Bell and Machin, 2016), but when inequality is tested as one among other explanatory factors, it seems to be insignificant (e.g. Becker, Fetzel and Novy, 2017). ${ }^{11}$ Instead, other economic dimensions seem to be more relevant. For instance, Algan et. al. (2017) finds that a 1\% increase in regional unemployment leads to a 12 to $18 \%$ increase in the share of Brexit vote in the region. Colantone and Stanig (2018a) show that regions more exposed to Chinese imports were also more likely to vote for Brexit. Fetzer (2018) finds austerity-induced welfare reforms since 2010 explain a significant rise in UKIP support (which is extremely highly correlated with voting Leave; Ashcroft, 2016) and on the vote for Brexit.

More generally, studies already mentioned and others (e.g. Alabrese et. al. 2018; Ashcroft, 2016; Pastor and Veronesi, 2017), either using causal or only correlation methods, find Brexit votes to be associated with being white, male, less educated, poorer, older, and not in employment. ${ }^{12}$ Others suggest there is an important cultural component - in terms of attitudes associated with migration, EU integration and policies like death penalty - which can predict Brexit voting more than economic factors (e.g. Kaufmann, 2016). Regarding immigration, the evidence seems to suggest some pro-Brexit effect (albeit with diverging sizes), particularly immigration from recently joined EU countries (Becker, Fetzel and Novy, 2017; Clarke and Whittaker, 2016; Colantone and Stanig, 2018a). Becker and Fetzel (2017) for example find a positive but small increase on UKIP's support due to the rapid immigration into the UK from 2004 EU accession countries (e.g. Poland).

Taking stock of the evidence, research to date has found it difficult to directly identify the impact of rising inequality in the election of Donald Trump and the vote for Brexit in a well-defined econometric setting. Inequality may have played a role through indirect channels such as undermining trust and the legitimacy of the political class and system, which underpin the rise of populism. More broadly, the underlying forces such as globalisation and technological change tending to drive up inequality at

\footnotetext{
${ }^{11}$ Interestingly though, Pastor and Veronesi (2017) find that voters who, at the moment of the survey, considered inequality to be bad (encompassing those who perceived a rise in inequality in the UK in the last 20 years and dislike it and those who perceived a fall in inequality in the same period and like it) show greater support for Brexit.

${ }^{12}$ Liberini et. al. (2017) find that only the very young had a clear pro-Remain preference, and being unemployed had no significant effect on voting for Brexit. The latter might be the case however because the authors also control for the individual's feeling regarding their financial situation, which is found to be a significant predictor of voting Leave and likely to be correlated with unemployment.
} 
country level and between regions, mediated by institutions and policies (e.g. Helpman, 2017; Nolan, 2018b), also set the context for such political debates and outcomes. Non-economic factors, often found relevant in explaining populism, may be linked as much to perceptions of economic insecurity and fears for the future as to rising income inequality per se.

\section{CONCLUSIONS}

Rising inequality in income and wealth is now centre-stage, not least due to the impact it is perceived to have on political behaviour and the support for populist parties. The 'grand narrative' that a sustained rise in income inequality is driving stagnating real incomes around and below the middle, exacerbating social 'bads' and fuelling 'revolt against the elites' probably comes closer to reflecting the experience of the US than many other rich countries, but is not the whole story even there. More to the point, the US case is not representative of the experience of rich countries with respect to inequality and income growth over recent decades, which has been much more varied than this 'grand narrative' recognizes. This variation has major implications for understanding the drivers of rising inequality and for assessing the impact it has had on economic performance, social outcomes, and the political domain.

However, the fact that inequality has now moved centre stage provides a window of opportunity to design and implementing policies and strategies to halt or reverse the rise in income and wealth inequality and promote inclusive growth, goals that can be justified in their own right even if more instrumental rationales were set aside. A central message from analysis of the forces driving rising inequality is that policy matters: "the particular institutions and policies in place in an individual country at a particular point in time have a profound impact on the extent and nature of (those) inequalities and their societal significance" (Salverda et al., 2014, p. 3). As the recent book by the leading economic scholar of inequality over the last half-century puts it, "I do not accept that rising inequality is inevitable: it is not solely the product of forces outside our control. There are steps that can be taken by governments, acting individually or collectively, by firms, by trade unions and consumer organisations, and by us as individuals to reduce the present level of inequality." (Atkinson, 2015, p. $302)$. 


\section{References}

Aaronson, D. and Mazumder, B. (2008), 'Intergenerational Economic Mobility in the United States, 1940 to 2000', Journal of Human Resources, 43 (1), 139-172.

Acemoglu, D., Naidu, S., Restrepo, P. and Robinson, J. (2019), 'Democracy Does Cause Growth', Journal of Political Economy, 127 (1), 47-100.

Aghion, P., Caroli, E., Garcia-Penalosa, C., (1999), 'Inequality and economic growth: the perspective of the new growth theories', Journal of Economic Literature, 37 (4), $1615-1660$.

Alabrese, E., Becker, S., Fetzer, T. and Novy, D. (2018), 'Who Voted for Brexit? Individual and Regional Data Combined', CESifo Working Paper Series No. 7193, Munich, CESifo.

Alesina, A. and Perotti, R. (1996), 'Income distribution, political instability, and investment', European Economic Review, 40 (6), 1203-1228.

Alesina, Al. and Giuliano, P. (2015), 'Culture and Institutions', Journal of Economic Literature, 53 (4), 898-944.

Algan, Yann, and Pierre Cahuc. 2014. "Trust, Growth, and Well-Being: New Evidence and Policy Implications.” In Handbook of Economic Growth, Volume 2A, edited by Philippe Aghion and Steven N. Durlauf, Amsterdam and San Diego, Elsevier, North-Holland, 49-120.

Algan, Y., Guriev, S., Papaioannou, E. and Passari, E. (2017), 'The European Trust Crisis and the Rise of Populism,' CEPR Discussion Papers 12444, C.E.P.R. Discussion Papers.

Algan, Y., Guriev, S., Papaioannou, E. and Passari, E. (2017), 'The European trust crisis and the rise of populism', Brookings Papers on Economic Activity, Fall, 309-82. Almond, D. and Currie, J. (2012), 'Human capital development before age five', in O. Ashenfelter and D. Card, Eds., Handbook of Labor Economics, Amsterdam, Elsevier, $1315-1486$.

Alvaredo et al, (2012) Alvaredo, F., Atkinson, A.B., Piketty, T. and Saez, E., (2013). The Top 1 Percent in International and Historical Perspective. Journal of Economic Perspectives, 27: 3-20. 
Alvaredo, F., Chancel, L., Piketty, T., Saez, E. and Zucman, G. (2017). 'Global Inequality Dynamics: New Findings from WID.world', American Economic Review Papers \& Proceedings, 107 (5), 404-409.

Alvaredo, F., L. Chancel, T. Piketty, E. Saez and G. Zucman (2018), World Inequality Report 2018, Paris, World Inequality Lab.

Andersen, R. (2012). 'Support for democracy in cross-national perspective: The detrimental effect of economic inequality', Research in Social Stratification and Mobility, 30 (4), 389-402.

Andrews, D. and Leigh, A. (2009), 'More inequality, less social mobility', Applied Economics Letters, 16 (15), 1489-1492.

Arpaia, A., Prez, E. and Pichelmann, K. (2009). 'Understanding Labour Income Share Dynamics in Europe', European Economy Economic Papers 379, May, Brussels, European Commission.

Ashcroft, M. (2016), 'How the United Kingdom voted on Thursday... and why', https://lordashcroftpolls.com/2016/06/how-the-united-kingdom-voted-and-why/

Atkinson, A.B. (2009). 'Factor shares: The principal problem of political economy?, Oxford Review of Economic Policy, 25(1), 3-16.

Atkinson, A.B. (2015), Inequality: What Can Be Done?, Cambridge, Mass., Harvard University Press.

Atkinson, A.B., Hassell, J., Morelli, S. and Roser, M. (2017). The Chartbook of Economic Inequality. Working Paper, Oxford, Institute for New Economic Thinking. Atkinson, A.B. and Piketty, T. eds. (2007), Top Incomes Over the Twentieth Century: A Contrast Between Continental European and English-Speaking Countries, Oxford, Oxford University Press.

Atkinson, A.B. and Piketty, T. eds. (2010). Top Incomes: A Global Perspective, Oxford, Oxford University Press.

Atkinson, A.B., Piketty, T. and Saez, E. (2011). 'Top Incomes in the Long Run of History'. Journal of Economic Literature 49 (1), 3-71. 
Autor, D., Katz, L. and Kearney, M. (2006), 'The Polarization of the US Labor Market', NBER Working Paper No. w11986, Cambridge Mass., National Bureau of Economic Research.

Autor, D., Dorn, D. and Hanson, G. (2016). 'The China Shock: Learning from LaborMarket Adjustment to Large Changes in Trade'. Annual Review of Economics, 8 (1), 205-240.

Autor, D., Dorn, D., Hanson, G. and Majilesi, K. (2017), 'Importing Political Polarization? The Electoral Consequences of Rising Trade Exposure', NBER Working Paper No. 22637, Cambridge, Mass., National Bureau of Economic Research.

Barber, M. (2016). 'Representing the Preferences of Donors, Partisans, and Voters in the U.S. Senate', Public Opinion Quarterly, 80 (S1), 225-249.

Barone, G., and Mocetti, S. (2016), 'Inequality and trust: new evidence from panel data', Economic Inquiry, 54 (2), 794-809.

Barro, R. (2000), 'Inequality and Growth in a Panel of Countries', Journal of Economic Growth, 5 (1), 5-32.

Becker, S., Fetzer, T. and Novy, D. (2017). 'Who Voted for Brexit? A Comprehensive District-Level Analysis', CEP Discussion Papers dp1480, Centre for Economic Performance, LSE.

Becker, S. and Fetzer, T. (2017). 'Did Eastern European immigration cause an increase in anti-European sentiment in the UK?', working paper, available at https://www.rse.anu.edu.au/media/2069116/Becker-paper-2017.pdf.

Belchior, A. M. (2013). 'Explaining Left-Right party congruence across European party systems: A test of micro-, meso-, and macro-level models', Comparative Political Studies, 46 (3), 352-386.

Bell, B. and Machin, S. (2016), Brexit and wage inequality, VoxEU, https://voxeu.org/article/brexit-and-wage-inequality

Bell, B. and Van Reenen, J. (2014). 'Bankers and Their Bonuses'. The Economic Journal 124, F1-F21.

Bentolila, S. and Saint-Paul, G. (2003). 'Explaining Movements in the Labor Share', Contributions to Macroeconomics, 3 (1), 1-33. 
Beugelsdijk, S., and Schaik, T. (2005). 'Differences in social capital between 54 Western European regions', Regional Studies, 39 (8), 1053-1064.

Björklund, A. (2006), "Does family policy affect fertility?," Journal of Population Economics, 19 (1), 3-24.

Blanden et. al. (2001, 2004) Blanden, J., Goodman, A., Gregg, P. and Machin, S. (2004), 'Changes in Intergenerational Mobility in Britain', in Miles Corak (ed.). Generational Income Mobility in North America and Europe, Cambridge, Cambridge University Press.

Blanden, Gregg and Macmillan, 2013). Blanden, J., Gregg, P., and Macmillan, L. (2013). 'Intergenerational persistence in income and social class: the effect of withingroup inequality', Journal of the Royal Statistical Society Series A, 176(2): 541-63.

Blumstein, A. and Wallman, J. eds, (2000). The Crime Drop in America, Cambridge, Cambridge University Press.

Bor, J. (2017), 'Diverging Life Expectancies and Voting Patterns in the 2016 US Presidential Election', American Journal of Public Health, 107 (10), 1560-1562.

Brady, H.E., Lehman Schlozman, K. and Verba, S. (2012), The Unholy Chorus: Unequal Political voice and the Broken Promise of American Democracy, Princeton, NJ, Princeton University Press.

Bukodi, E. and Goldthorpe, J.H. (2019), Social Mobility and Education in Britain: Research, Politics and Policy, Cambridge, Cambridge University Press.

Bukodi, E. and Paskov, M. (2018), 'Income Inequality, Living Standards, and Intergenerational Social Mobility', in B. Nolan ed., Generating Prosperity for Working Families in Affluent Countries, Oxford, Oxford University Press.

Calvert, E. and Fahey, T. (2013). Income Inequality and the Family, GINI Discussion Paper, Amsterdam, Amsterdam Institute for Labour Studies, http://giniresearch.org/articles/papers.

Calvert, E and Nolan, B. (2012). Deprivation, Income and Inequality in the EU, GINI Discussion Paper, Amsterdam, Amsterdam Institute for Labour Studies, http://giniresearch.org/articles/papers. 
Case, A. and Deaton, A. (2017), 'Mortality and Morbidity in the 21st Century', Brookings Papers on Economic Activity, Spring, 397-443.

Cavadino, M. and Dignan, J. (2006), Penal Systems: A Comparative Approach, London, Sage.

Chen, W.-H., Forster, M., Marshalian, M., Llena-Nozal, A. (2014), Women, Work and Wages: The Gender Aspect of Earnings and Household Income Inequality. OECD Social, Employment and Migration Working Papers, Paris, OECD.

Cherlin, A. (2018), 'How Economic Inequality Drives Family Formation and Dissolution', $\quad$ https://ifstudies.org/blog/how-economic-inequality-drives-familyformation-and-dissolution

Chetty, Hendren, Kline, Saez, Turner, 2014 Chetty, R., Hendren, N., Kline, P., Saez, E., and Turner N. (2014). 'Is the United States still a land of opportunity? Recent trends in intergenerational mobility', American Economic Review, 104(5): 141-7.

Chetty, R., Grusky, D., Hell, M., Hendren, N., Manduca, R. and Narang, J. (2016), 'The Fading American Dream: Trends in Absolute Income Mobility Since 1940', NBER Working Papers No 22910, Cambridge, Mass., National Bureau of Economic Research.

Christini, A., Geraci, A. and Muellbauer, J. (2018), 'Sifting through the ASHE: Job Polarization and Earnings Inequality in the UK, 1975-2015', in B. Nolan ed., Generating Prosperity for Working Families in Affluent Countries, Oxford, Oxford University Press.

Cingano, F. (2014), 'Trends in Income Inequality and Its Impact on Economic Growth', OECD SEM Working Paper No. 163, Paris, OECD.

Clarke, S. and Whittaker, M. (2016). 'The Importance of Place: explaining the characteristics underpinning the Brexit vote across different parts of the UK', available at http://www.resolutionfoundation.org/publications/the-important-of-placeexplaining-the-characteristics-underpinning-the-brexit-vote-across-different-parts-of$\underline{\text { the-ukl }}$

Colantone, I. and Stanig, P. (2018a), 'Global Competition and Brexit', American Political Science Review, 112 (2), 201-218. 
Colantone, I. and Stanig, P. (2018b), 'The Trade Origins of Economic Nationalism: Import Competition and Voting Behavior in Western Europe', American Journal of Political Science, 62, 936-953.

Corak, M. (2012), 'Inequality from generation to generation: the United States in Comparison', Working Paper, available at http://nws-sa.com/rr/Inequality/inequalityfrom- generation-to-generation-the-united-states-in-comparison-v3.pdf

Currie, J. (2009), 'Healthy, wealthy, and wise: socioeconomic status, poor health in childhood, and human capital development', Journal of Economic Literature, 47 (1), 87-122.

Cutler, D., Lleras-Muney, A. and Vogl, T. (2011), 'Socioeconomic status and health: dimensions and mechanisms', in The Oxford Handbook of Health Economics, ed. S. Glied and P. Smith, Oxford, Oxford University Press.

Cynamon, B.Z. and Fazzari, S.M. (2014), 'Inequality, the Great Recession, and Slow Recovery', Cambridge Journal of Economics, 40(2), 373-399

Dabla-Norris, E., Kochhar, K., Ricka, F., Suphaphiphat, N. and Tsounta, E. (2015), 'Causes and Consequences of Income Inequality: A Global Perspective', Staff Discussion Notes No. 15/13, Washington DC, International Monetary Fund.

Daly, M., Wilson, M., Vasdev, S. (2001), 'Income inequality and homicide rates in Canada and the United States', Canadian Journal of Public Health, 43, 219-236.

Darvas, Z. and Efstathiou (2016), 'Income inequality boosted Trump vote', available at http://bruegel.org/2016/11/income-inequality-boosted-trump-vote/

Denk, O. (2015). Who are the top 1\% earners in Europe? OECD Economics Department Working Papers 1274. Paris, OECD.

Dippel, C., Gold, R., and Heblich, S. (2015), 'Globalization and Its (Dis-)Content: Trade Shocks and Voting Behavior', NBER Working Papers 21812, Cambridge, Mass., National Bureau of Economic Research.

Dincer, O., and Uslaner, E. (2010). 'Trust and growth', Public Choice, 142 (1), 5967.Dragolov, G., Ignácz, Z. S., Lorenz, J., Delhey, J., Boehnke, K., and Unzicker, K. (2016), Social Cohesion in the Western World: What Holds Societies Together: Insights from the Social Cohesion Radar, Springer Briefs in Well-Being and Quality of Life Research, Switzerland. 
Dustmann, C., Eichengreen, B., Otten, S., Sapir, A., Tabellini, G. and Zoega, G. (2017), Europe's Trust Deficit: Causes and Remedies, Monitoring International Integration 1, CEPR Press.

Economic Report of the President (2015), Economic Report of the President Together with the Annual Report of the Council of Economic Advisers, Transmitted to the Congress February 2015, Washington, D.C., Council of Economic Advisers.

El-Shagi, M. and Shao, L. (2017). 'The Impact of Inequality and Redistribution on Growth', Review of Income and Wealth, DOI: 10.1111/roiw.12342.

Enzmann Enzmann, D., Marshall, I., Killias, M., Junger-Tas, J., Steketee, M. Gruszczyńska, B. et al., (2010), 'Self-reported youth delinquency in Europe and beyond', European Journal of Criminology 7(2):159-183

Epp, D. and Borghetto, E. (2018), 'Economic Inequality and Legislative Agendas in Europe', working paper, available at https://enricoborghetto.netlify.com/working_paper/EuroInequality.pdf.

ERCAS (2015), 'Public Integrity and Trust in Europe', http://www.eupan.eu/files/repository/20160202135959_2016-01-

21_Public_integrity_and_trust_in_Europe_-_final.pdf

Erikson, R. and Goldthorpe, J. (2010). 'Has Social Mobility in Britain Decreased? Reconciling Divergent Findings on Income and Class Mobility', British Journal of Sociology, 61, 211-30.

Eurofound (2014), Drivers of Recent Job Polarisation and Upgrading in Europe: European Jobs Monitor 2014, Luxembourg: Publications Office of the European Union.

Fajnzylber, P., Lederman, D., Loayza, N. (2002), 'Inequality and violent crime', Journal of Law and Economics, 45, 1-40.

Fernandez-Macias, E. (2012) 'Job Polarization in Europe? Changes in the Employment Structure and Job Quality, 1995-2007', Work and Occupations, 39, 157182.

Fesseau M. and Mattonetti, M. (2013). 'Distributional measures across house- hold groups in a national accounts framework: Results from an experimental cross-country 
exercise on household income, consumption and saving', OECD Statistics Working Papers No. 2013/04, Paris, OECD.

Fesseau Wolff, F. and Mattonetti, M. (2013). 'A cross-country comparison of household income, consumption and wealth between micro sources and national accounts aggregates', OECD Statistics Working Papers No. 2013/03, Paris, OECD.

Fetzer, T. (2018), 'Did austerity cause Brexit?', Warwick economics research papers series 1170, Coventry, University of Warwick.

Fixler, D. and Jaditz, T. (2002). 'An examination of the difference between the CPI and the price deflator', BLS Working Paper no. 361, Washington DC., Bureau of Labor Statistics.

Fixler, D., Johnson, D., Craig, A. and Furlong, K. (2015). 'A consistent data series to evaluate growth and inequality in the national accounts', Technical report, Washington D.C., Bureau of Economic Analysis.

Förster, M. and Tóth, I. G. (2015), 'Cross-Country Evidence of the Multiple Causes of Inequality Changes in the OECD Area', in A.B. Atkinson and F. Bourguignon eds., Handbook of Income Distribution, Volume 2, Amsterdam, North-Holland, 17291843.

Foster, C. and Frieden, J. (2017), 'Crisis of trust: Socio-economic determinants of Europeans' confidence in government'. European Union Politics, 18 (4), 511-535.

Gilens, M. (2012), Affluence and Influence: Economic Inequality and Political Power in America, Princeton, NJ, Princeton University Press.

Gimpel, J.G. (2017), 'Immigration Policy Opinion and the 2016 Presidential Vote', available at https://cis.org/Report/Immigration-Policy-Opinion-and-2016-PresidentialVote.

Glaeser, E. (2008), 'Inequality', in D. Wittman and B. Weingast eds., The Oxford Handbook of Political Economy, Oxford, Oxford University Press.

Goldthorpe, J. H. (2013). 'Understanding — and misunderstanding — social mobility in Britain: the entry of the economists, the confusion of politicians and the limits of educational policy', Journal of Social Policy, 42: 431-50 
Goldthorpe, J. H. (2016). 'Social class mobility in modern Britain: changing structure, constant process', Journal of the British Academy, 2016(4): 89-111.

Goos M. and Manning, A. (2007), 'Lousy and Lovely Jobs: The Rising Polarization of Work in Britain', Review of Economics and Statistics, 89 (1), 118-133.

Goos M., Manning, A. and Salomons, A. (2009), 'Job Polarization in Europe', American Economic Review, 99 (2), 58-63.

Goos, M., Manning, A. and Salomons, A. (2014). 'Explaining Job Polarization: Routine- Biased Technological Change and Offshoring'. American Economic Review 104, 2509- 26.

Gould, E. and Hijzen, A. (2016), 'Growing Apart, Losing Trust? The Impact of Inequality on Social Capital', IMF Working Papers 16/176, Washington D.C., International Monetary Fund.

Green, J. and McElwee, S. (2018), 'The Differential Effects of Economic Conditions and Racial Attitudes in the Election of Donald Trump', Perspectives on Politics, 1-22.

Guiso, L., Sapienza, P. and Zingales, L. (2006), 'Does Culture Affect Economic Outcomes?', Journal of Economic Perspectives, 20 (2), 23-48.

Guiso, L., Herrera, H., Morelli, M. and Sonno, T. (2017), 'Demand and Supply of Populism," CEPR Discussion Papers 11871, London, CEPR.

Healy, D., Mulcahy, A. and I. O'Donnell (2013). Crime, Punishment and Inequality in Ireland, GINI Discussion Paper, Amsterdam, Amsterdam Institute for Labour Studies, http://www.gini-research.org/articles/papers.

Heckman, J.J. (2007), 'The economics, technology, and neuroscience of human capability formation. Proceedings of the National Academy of Science U.S.A., 104 (33), 13250-13255.

Heidrich, S. (2015), 'Intergenerational mobility in Sweden: a regional perspective', No 916, Umeå Economic Studies, Umeå University.

Heinö, A. J. (2018), 'Timbro Authoritarian Populism Index 2017', working paper, available at https://timbro.se/allmant/timbro-authoritarian-populism-index2017/

Helpman, E. (2017), 'Globalization and Wage Inequality', Journal of the British Academy, 5, 125-162. 
Hills, J., McKnight, A., Bucelli, I., Karagiannaki, E., Vizard, P. and Yang, L. with Duque, M. and Rucci, M. (2019), Understanding the Relationship between Poverty and Inequality: Overview Report, CASE Report No. 119, London, London School of Economics and Political Science.

Holmes, C. (2018), 'The Labour Market: Wage Inequality, Occupations, and Mobility', in B. Nolan ed., Generating Prosperity for Working Families in Affluent Countries, Oxford, Oxford University Press.

Horn, D. (2011), 'Income Inequality and Voter Turnout', GINI Discussion Papers No. 16, Amsterdam, Amsterdam Institute for Advanced Labour Studies.

Horvath, R. (2013). 'Does trust promote growth?', Journal of Comparative Economics, 41 (3), 777-788.

Hsieh, C.-C., Pugh, M.D. (1993), 'Poverty, income inequality, and violent crime: a meta-analysis of recent aggregate data studies', Criminal Justice Review, 18, 182-202. ILO/OECD (2015), The Labour Share in G20 Economies, Report prepared for the G20 Employment Working Group Antalya, Turkey, Geneva/Paris, ILO and OECD.

Immervoll, H. and Richardson, L. (2011), Redistribution policy and inequality reduction in OECD countries what has changed in two decades? OECD Social, Employment and Migration Working Papers no. 122, Paris, OECD.

Inglehart, R.F. and Norris, P. (2016), 'Trump, Brexit, and the Rise of Populism: Economic Have-Nots and Cultural Backlash', Faculty Research Working Paper Series RWP16-026, Cambridge, Mass., Harvard Kennedy School.

Irwin D.A. (2016), 'The truth about trade: What critics get wrong about the global economy', Foreign Affairs. 95, 84-95.

Irwin, N., and Katz, J. (2016), 'The Geography of Trumpism', available at https://www.nytimes.com/2016/03/13/upshot/the-geography-of-trumpism.html

Jaime-Castillo, A. (2009), 'Economic Inequality and Electoral Participation: A CrossCountry Evaluation', presented at Comparative Study of the Electoral Systems Conference, Toronto, Canada. 
Jenkins, S.P, Brandolini, A., Micklewright, J. and Nolan, B. eds. (2013), The Great Recession and the Distribution of Household Income, Oxford, Oxford University Press.

Jordahl, H. (2009), 'Economic inequality', in G. T. Svendsen and G. L. H. Svendsen, (eds.), Handbook of Social Capital, Cheltenham, Edward Elgar.

Jorgenson, D. W. and Slesnick, D. (2014), 'Measuring Social Welfare in the U.S. National Accounts', in D. W. Jorgenson, J. Landefeld, and P. Schreyer (eds), Measuring Economic Sustainability and Progress, Cambidge, Mass., NBER, 43-88.

Karabarbounis L. and Neiman, B. (2014). 'The Global Decline of the Labor Share', The Quarterly Journal of Economics, 129 (1), 61-103.

Kaufmann, E. (2016) 'It's NOT the economy, stupid: Brexit as a story of personal values' British Politics and Policy at LSE (07 Jul 2016) available at http://eprints.1se.ac.uk/71585/

Kenworthy, L. and Smeeding, T. (2013), 'The USA: High and Rising Inequality', in Nolan, B., Salverda, W., Checchi, D., Marx, I., McKnight, A., Tóth, I. and van de Werfhorst, H. eds., Changing Inequalities and Societal Impacts in Rich Countries: Thirty Countries' Experiences, Oxford, Oxford University Press.

Kilcommins, S., O’Donnell, I., O’Sullivan. E. and Vaughan, B. (2004), Crime, Punishment and the Search for Order in Ireland. Dublin, IPA.

Knowles, E. D. and Tropp, L. R. (2018), 'The Racial and Economic Context of Trump Support: Evidence for Threat, Identity, and Contact Effects in the 2016 Presidential Election', Social Psychological and Personality Science, 9 (3), 275-284.

Komlos, J. (2018), 'The Economic Roots of the Rise of Trumpism', CESifo Working Paper Series 6868, Munich, CESifo Group.

Kourtellos, C. and Tsangarides, G. (2015). 'Robust Correlates of Growth Spells: Do Inequality and Redistribution Matter?', Working Paper 15-20, Rimini, Rimini Centre for Economic Analysis.

Kuhn, T., Hakhverdian, A., Van Elsas, E. and Van der Brug, W. (2013). 'Euroscepticism and education: A longitudinal study of 12 EU member states, 19732010', European Union Politics, 14 (4), 522-541. 
Kyle, J. and Gultchin, L. (2018), 'Populists in Power Around the World, working paper, available at https://institute.global/insight/renewing-centre/populists-poweraround-world

Lacey, N. (2008), The Prisoners' Dilemma: Political Economy and Punishment in Contemporary Democracies, Cambridge, Cambridge University Press

Lancee, B. and Van de Werfhorst, H. (2012), 'Income inequality and participation: A comparison of 24 European countries', Social Science Research, 41 (5), 1166-1178.

Lappi-Seppala, T. (2008), 'Trust, welfare and political culture: explaining differences in national penal policies', in M. Tonry (ed) Crime and Justice: A Review of Research, Vol. 37, Chicago, University of Chicago Press.

Lee, C. and Solon, G. (2009), 'Trends in Intergenerational Income Mobility', The Review of Economics and Statistics, 91(4), 766-772.

Lefranc, A. (2011). 'Educational expansion, earnings compression and changes in intergenerational economic mobility: Evidence from French cohorts, 1931-1976', THEMA Working Papers No 2011-11, Université de Cergy-Pontoise.

Lefranc, A., Ojima, F., and Yoshida, T. (2014). 'Intergenerational earnings mobility in Japan among sons and daughters: levels and trends', Journal of Population Economics, 27(1): 91-134.

Leigh, A. (2007), 'Intergenerational mobility in Australia', The B.E. Journal of Economic Analysis \& Policy, 7(2), 1-28.

Leigh, A., Jencks, C. and Smeeding, T. (2008) in Salverda, W., Nolan, B. and Smeeding, T. eds. The Oxford Handbook of Economic Inequality, Oxford, Oxford University Press.

Lesschaeve, C. and Bernhard, L. (2014), 'Voters, business, or unions - Who cues views of national MPs on European integration?', Paper prepared for the ECPR General Conference at the University of Glasgow, https://ecpr.eu/Filestore/PaperProposal/09439c08-f01d-4719-97dd-2238ded71635.pdf Liberini, F., Oswald, A., Proto, E. and Redoano, M. (2017), 'Was Brexit Caused by the Unhappy and the Old?', IZA Discussion Papers 11059, Bonn, Institute for the Study of Labor (IZA). 
Lubos, P. and Veronesi, P. (2018), 'Inequality Aversion, Populism, and the Backlash Against Globalization,' NBER Working Papers 24900, Cambridge, Mass., National Bureau of Economic Research.

Malgouyres, C. (2017). 'Trade Shocks and Far-Right Voting: Evidence from French Presidential Elections', Robert Schuman Centre for Advanced Studies Research Paper No. RSCAS 2017/21, Florence, European University Institute.

Major, B., Blodorn, A., and Blascovich, G. M. (2018), 'The threat of increasing diversity: Why many White Americans support Trump in the 2016 presidential election', Group Processes \& Intergroup Relations, 21 (6), 931-940.

Mazzucato, M. (2013), The Entrepreneurial State - Debunking Public vs. Private Sector Myths, London, Anthem Press.

Mudde, C. (2007), Populist Radical Right Parties in Europe, Cambridge, Cambridge University Press.

Mutz, D. (2018), 'Status threat, not economic hardship, explains the 2016 presidential vote', Proceedings of the National Academy of Sciences, 115 (19), E4330-E4339.

Nolan, B. ed. (2018a), Inequality and Inclusive Growth in Rich Countries: Shared Challenges and Contrasting Fortunes, Oxford University Press, Oxford.

Nolan, B. ed. (2018b), Generating Prosperity for Working Families in Affluent Countries, Oxford, Oxford University Press.

Nolan, B., Leventi, C., Sutherland, H. and Tasseva, I. (2018), in B. Nolan ed., Generating Prosperity for Working Families in Affluent Countries, Oxford, Oxford University Press, 259-81.

Nolan, B. and Marx, I. (2009). 'Inequality, Poverty and Social Exclusion', in Salverda, W., Nolan, B. and Smeeding, T. eds. The Oxford Handbook of Economic Inequality, Oxford: Oxford University Press.

Nolan, B., Salverda, W., Checchi, D., Marx, I., Mcknight, A., Tóth, I.G., van de Werfhorst, H. (eds, 2014), Changing Inequalities and Societal Impacts in Rich Countries: Thirty Countries Experiences, Oxford, Oxford University Press. 
Nolan, B., Roser, M. and Thewissen, S. (2018), 'Median Household Income and GDP', in B. Nolan ed., Generating Prosperity for Working Families in Affluent Countries, Oxford, Oxford University Press, 85-110.

Nolan and Thewissen (2018a), 'The Evolution of Living Standards for Middle and Lower Income Households in OECD Countries' in B. Nolan ed., Generating Prosperity for Working Families in Affluent Countries, Oxford, Oxford University Press, 13-48.

Nolan, B. and Thewissen, S. (2018b), 'Inequality and Ordinary Living Standards in OECD Countries', in B. Nolan ed., Generating Prosperity for Working Families in Affluent Countries, Oxford, Oxford University Press, 49-84.

Nolan, B. and Whelan, C.T. (2014), 'The Social Impact of Income Inequality: Poverty, Deprivation and Social Cohesion', in Salverda, W., Nolan, B., Checchi, D., Marx, I., McKnight, A., Tóth, I.G. and van de Werfhorst, H. (eds), (2014), Changing Inequalities in Rich Countries: Analytical and Comparative Perspectives, Oxford, Oxford University Press.

Norris P. (1997), Passages to Power: Legislative Recruitment in Advanced Democracies, Cambridge, UK: Cambridge University Press.

OECD, (2008), Growing Unequal, Paris, OECD.

OECD, (2011), Divided We Stand: Why Inequality Keeps Rising, Paris, OECD.

OECD (2015), In It Together: Why Less Inequality Benefits All, Paris, OECD.

OECD (2018), A Broken Social Elevator? How to Promote Social Mobility, Paris, OECD.

OECD (2019), Trends Shaping Education 2019, Paris, OECD.

Oesch, D. (2013). Occupational Change in Europe: How Technology and Education Transform the Job Structure, Oxford, Oxford University Press.

Olivera, J. (2015), 'Changes in Inequality and Generalized Trust in Europe', Social Indicators Research, 124(1), 21-41.

O'Donnell O, Van Doorslaer E, Van Ourti T. (2015), 'Health and inequality', Handbook of Income Distribution, vol. 2, Amsterdam, Elsevier, 1419-533. 
Okun, A. (1975). Equity and Efficiency: The Great Trade-Off, Washington D.C., Brookings Institute.

Ostry, J.D., Berg, A., and Tsangarides, C. (2014), 'Redistribution, Inequality, and Growth', IMF Staff Discussion Note, SDN/14/02, Washington DC., International Monetary Fund.

Page, B., Bartels, L., and Seawright, J. (2013), 'Democracy and the Policy Preferences of Wealthy Americans', Perspectives on Politics, 11 (1), 51-73.

Parvin, P. (2018), 'Democracy Without Participation: A New Politics for a Disengaged Era', Res Publica, 24 (1), 31-52.

Paskov, M. and C. Dewilde, (2012), 'Income Inequality and Solidarity in Europe', Research in Social Stratification and Mobility, 30 (4), 415-432.

Pekkala, S. and Lucas, R. (2005). 'On the Importance of Finnishing School: Half a Century of Inter-generational Economic Mobility in Finland', Discussion Papers 359, Helsinki, VATT Institute for Economic Research.

Pekkarinen, T., Salvanes, K., and Sarvimäki, M. (2017). 'The Evolution of Social Mobility: Norway over the 20th Century', Scandinavian Journal of Economics, 119 (1), 5-33, 2017

Pickett, K.E., Wilkinson, R.G. (2015), 'Income inequality and health: A causal review', Social Science \& Medicine, 128, 316-26.

Piketty, T. (2013), Capital in the Twenty-First Century, Cambridge, Mass., Harvard University Press.

Piketty, T., Saez, E. and Zucman, G. (2018), 'Distributional National Accounts: Methods and Estimates for the United States' The Quarterly Journal of Economics, 133(2), 553-609.

Pridemore, W.A. and Trent, C. (2010), 'Do the Invariant Findings of Land, McCall, and Cohen Generalize to Cross-National Studies of Social Structure and Homicide', Homicide Studies, 14, 296-335)

Rajan, R. (2010). Fault Lines: How Hidden Fractures Still Threaten the World Economy, Princeton, Princeton University Press. 
Raleigh, V. (2019), 'Trends in life expectancy in EU and other OECD countries: Why are improvements slowing?', OECD Health Working Papers, No. 108, Paris, OECD.

Reich, R. (2010). Aftershock: The Next Economy and America's Future, New York, Random House.

Robinson, J., Acemoglu, D. and Johnson, S. (2005), 'Institutions as a Fundamental Cause of Long-Run Growth', Handbook of Economic Growth Vol. 1A, Amsterdam, Elsevier, 386-472.

Rodrik, D. (2018), 'Populism and the economics of globalization,' Journal of International Business Policy, 1 (1-2), 12-33.

Rothwell, J. and Diego-Rosell, P. (2016), 'Explaining Nationalist Political Views: The Case of Donald Trump', available at http://dx.doi.org/10.2139/ssrn.2822059.

Rufrancos, H., Power, M., Pickett, K.E., Wilkinson, R. (2013), 'Income inequality and crime: a review and explanation of the time-series evidence', Sociology and Criminology, 1(1), 1-9.

Salverda, W., Nolan, B., Checchi, D., Marx, I., McKnight, A., Tóth, I.G. and van de Werfhorst, H. (eds), (2014), Changing Inequalities in Rich Countries: Analytical and Comparative Perspectives, Oxford, Oxford University Press.

Schaffner, B.F., Macwilliams, M. and Nteta, T. (2018), 'Understanding White Polarization in the 2016 Vote for President: The Sobering Role of Racism and Sexism’, Political Science Quarterly, 133 (1), 9-34.

Slaughter, M. and Swagel, P. (1997). 'The Effects of Globalisation on Wages in Advanced Economies', IMF WP 97/43, Washington D.C., International Monetary Fund.

Smith, D. N., and Hanley, E. (2018), 'The Anger Games: Who Voted for Donald Trump in the 2016 Election, and Why?', Critical Sociology, 44 (2), 195-212.

Solt, F. (2008), 'Economic Inequality and Democratic Political Engagement', American Journal of Political Science, 52 (1), 48-60.

Solt, F. (2010), 'Does Economic Inequality Depress Electoral Participation? Testing the Schattschneider Hypothesis’, Political Behavior, 32 (2), 285-301. 
Solt, F. (2016), 'The Standardized World Income Inequality Database', Social Science Quarterly, 97 (5), 1267-1281.

Stein, S. and Lancee, B. (2011), 'Does Income Inequality Negatively Affect General Trust?', GINI Discussion Paper 14, Amsterdam, Amsterdam Institute for Advanced Labour Studies.

Stiglitz. J. (2012), The Price of Inequality, New York, W.W. Norton.

Stiglitz, J. (2015), The Great Divide: Unequal Societies and What We Can Do About Them, New York, W.W. Norton.

Thewissen, S., Kenworthy, L., Nolan, B., Roser, M. and Smeeding, T. (2018), 'Rising Inequality and Living Standards in OECD Countries: How Does the Middle Fare?',

Tóth, I.G. (2014), 'Revisiting Grand Narratives of Growing Inequalities: Lessons From 30 Country Studies', in B. Nolan et al eds., Changing Inequalities and Societal Impacts in Rich Countries Thirty Countries' Experiences, Oxford, Oxford University Press.

Tseloni, A., Mailley, J., Farrell, G. and Tilley, N. (2010), 'Exploring the international decline in crime rates', European Journal of Criminology, 7(5), 375-94.

Truesdale, B. and Jencks, C. (2016), 'The Health Effects of Income Inequality: Averages and Disparities', Annual Review of Public Health, 37, 413-30.

Urbinati, N. (2019), 'Political Theory of Populism', Annual Review of Political Science, 22, forthcoming.

Uslaner, E. M. (2016), 'A Reconsideration of Olivera's "Changes in Inequality and Generalized Trust in Europe"', Social Indicators Research, 128 (2), 723-729.

Uslaner, E. M., and Brown, M. (2005). 'Inequality, Trust, and Civic Engagement', American Politics Research, 33 (6), 868-894.

Voitchovsky, S. (2005), 'Does the Profile of Income Inequality Matter for Economic Growth?', Journal of Economic Growth, 10 (3), 273-296.

Wilkinson, R. and Pickett, K. (2010), The Spirit Level: Why Equality Is Better for Everyone, Harmondsworth, Penguin.

Wilkinson, R.G. and Pickett, K. (2018), The Inner Level, London, Allen Lane. 
Zak, P., and Knack, S. (2001). 'Trust and Growth', Economic Journal, 111 (470), 295-321.

Zimring, F. (2007). The Great American Crime Decline, New York, Oxford University Press. 